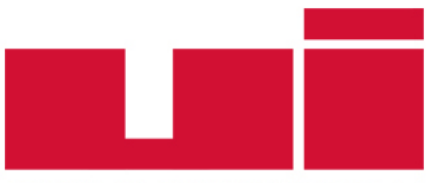

ULUUSLARARASIILIŞKiLER

Akademik Dergi

Yayın ilkeleri, izinler ve abonelik hakkında ayrıntılı bilgi:

E-mail: bilgi@uidergisi.com.tr

Web: www.uidergisi.com.tr

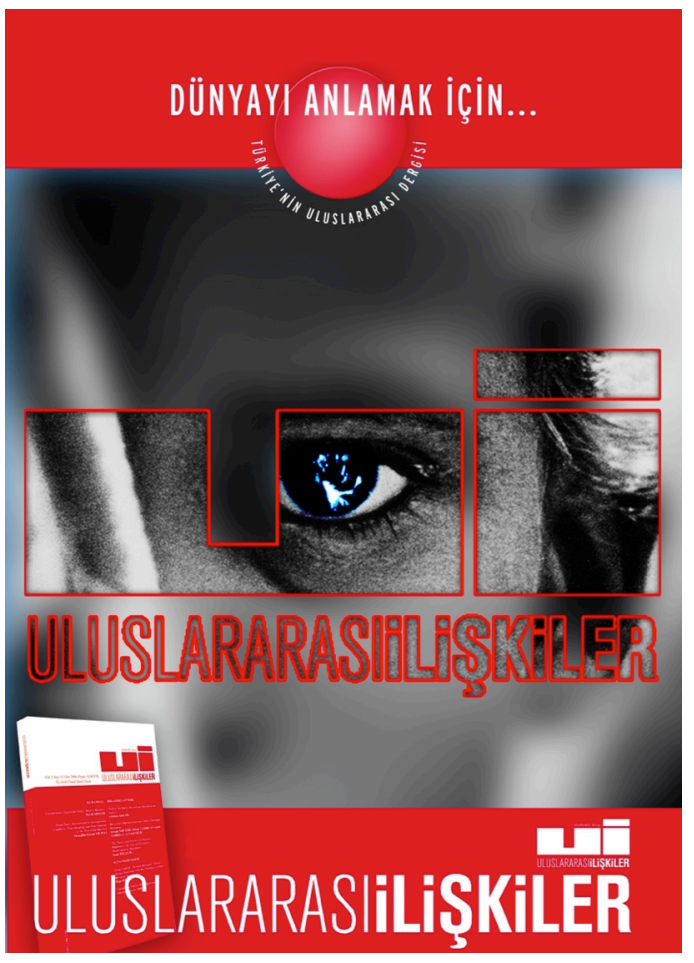

\title{
Uluslararası İlişkilerde Bilimsellik, Metodoloji ve Yöntem
}

Nil S. ŞATANA*

* Doç. Dr., Bilkent Üniversitesi, Uluslararası İlişkiler Bölümü

Bu makaleye atıf için: Şatana, Nil S., "Uluslararası İlișkilerde Bilimsellik, Metodoloji ve Yöntem", Uluslararası Illişkiler, Cilt 12, Say1 46, s. 11-33.

$\mathrm{Bu}$ makalenin tüm hakları Uluslararası İlişkiler Konseyi Derneği'ne aittir. Önceden yazılı izin alınmadan hiç bir iletişim, kopyalama ya da yayın sistemi kullanılarak yeniden yayımlanamaz, çoğaltılamaz, dağıtılamaz, satılamaz veya herhangi bir şekilde kamunun ücretli/ücretsiz kullanımına sunulamaz. Akademik ve haber amaçlı kısa alıntılar bu kuralın dışındadır.

Aksi belirtilmediği sürece Uluslararası Illişkiler'de yayınlanan yazılarda belirtilen fikirler yalnızca yazarına/yazarlarına aittir. UİK Derneğini, editörleri ve diğer yazarları bağlamaz.

Uluslararası İlişkiler Konseyi Derneği | Uluslararası İlişkiler Dergisi

Web: www.uidergisi.com.tr | E- Posta: bilgi@uidergisi.com.tr 


\title{
Uluslararası İlişkilerde Bilimsellik, Metodoloji ve Yöntem
}

\author{
Nil S. ŞATANA \\ Doç. Dr., Uluslararası İlişkiler Bölümü, Bilkent Üniversitesi, Ankara. E-posta: nsatana@bilkent.edu.tr.
}

\section{ÖZET}

Uluslararası İlişkiler, sadece kuramsal açıdan değil, bilim felsefesi anlayışı konusunda da derin fikir ayrılıkları yaşayan bir disiplindir. Öyle ki, epistemoloji, ontoloji ve metodoloji konularında yaşanan anlaşmazlıklar Uluslararası İlişkilerin disiplin olma özelliğini dahi sorgulatmaktadır. Bu makale, Uluslararası İlişkilerde özellikle metodoloji ve yöntem konularında yaşanan tartışmaları özetlemeyi, metodolojiyle ilgili kavramları açıklığa kavuşturmayı ve metot konusuna faydacı bir bakış açısı getirmeyi hedeflemektedir. Rudra Sil ve Peter Katzenstein, analitik uzlaştırmacılık (analytic eclecticism) yaklaşımları ile farklı bakış açılarının kuram ve epistemoloji gibi konularda anlaşmadan da birbirlerini tamamlayabileceğini, dünya siyasetini anlamlandırabilmek için faydacı bir yaklaşım kullanmanın gerekli olduğunu iddia etmektedirler. Makale, bu uzlaştırmacı yaklaşımın araştırma metotları konusunda da kullanılabileceğini terörizm çalışmalarından örneklerle göstermektedir.

\section{Scientificity, Methodology and Method in International Relations}

\begin{abstract}
International Relations is a highly divided discipline regarding not only theory but also philosophy of science. Thus, it is often questioned whether the discipline is so divided in epistemology, ontology and methodology is no longer a discipline. This article seeks to clarify the major concepts used in methodology, summarize the main debates in the discipline and to bring a pragmatic approach to research methods in international relations. In their research approach called analytic eclecticism, Rudra Sil and Peter Katzenstein argue that different theories and paradigms do not need to agree on everything to complement each other's weaknesses. Instead, we need the best of all worlds to understand and explain the complex phenomena that take place in world politics. This article argues that this eclectic approach can also be used in research methods and demonstrates how pragmatism has improved terrorism studies.
\end{abstract}

Keywords: Methodology, Method, Scientific Knowledge, Ontology, Epistemology, Analytic Eclecticism 


\section{Giriş}

Uluslararası İlişkilerde bilimsellik ve metodoloji üzerine 1950'lerden bu yana çok sayıda çalışma yapılmıştır. ${ }^{1} \mathrm{Bu}$ çalışmalar genellikle kuram ve metodolojiyi bir arada incelemişlerdir. Zira, metodoloji ile ilgili herhangi bir yazıda kuramdan hiç bahsetmemek mümkün değildir. Bu sebeple bu makalede de yeri geldikçe kuram ve metodoloji ilişkisi ele alınacaktır. Fakat makalenin birincil amacı, farklı kuram ya da paradigmaların epistemoloji ve ontolojide ayrılsalar dahi, kullandıkları metotların da birbirlerinden tamamen ayrışması gerekip gerekmediğini sorgulamaktır. Uluslararası İlişkiler akademisyenlerinin araştırmalarında kullandıkları yöntemler konusunda kutuplaşmış olmaları, yapılan çalışmalar ne kadar değerli olursa olsun, tarafların birbirlerini dikkate almadı̆̆ bir ortam oluşturmuştur. Öyle ki, çoğu zaman pozitivist araştırma prensiplerini benimsemiş olanlar, bilişsel (cognitivist) ve yorumsamacı (interpretive) araştırma yapan eleştirel veya post-pozitivist akademisyenleri "hayal dünyasında yaşamak" ve "keyfe keder örnek olay seçmek" ile itham etmekte, post-pozitivist gelenekten gelenler ise pozitivistleri "sayılarla uğraşanlar" (number cruncher) ya da "istatistiklerle yalan söyleyenler" olarak değerlendirebilmektedirler. ${ }^{2}$

Bu makale, bu iki farklı dünya görüşü ve metodolojik yaklaşımın birbirleriyle epistemoloji ve ontoloji konularında anlaşmak zorunda kalmadan da birbirlerinden faydalanabileceklerini öne süren literatürü benimsemekte ve sadece metodoloji değil, metot üzerine de tartışma açmayı hedeflemektedir. Ayrıca, bu konu Türkiye'de de tartışılmaktaysa da, genelde metodoloji ve özelde metot kullanımına eğilen az sayıda çalışma bulunduğundan, bu makale ile bu konudaki boşluk da giderilmeye çalışılacaktır. ${ }^{3}$ Özünde, makalede yeni bir sav ortaya koyma iddiası bulunmamakta, konuyla ilgili tartışmalar değerlendirilerek çatışma ve terörizm literatüründen örneklerle metoda pragmatik bir yaklaşımın gösterilmesi hedeflenmektedir.

Kuram, metodoloji, epistemoloji ve ontoloji tartışmaları ve anlaşmazlıklarının Uluslararası İliş̧kiler disiplininin genel bir parçası haline geldiği bugünkü ortamda, araştırmalarda bir metodun diğerine tercih edilme nedeni önemlidir. Bu makalenin ana hedefi, metot seçiminde önemli olanın araştırmacının epistemolojik ya da ontolojik kaygılarından ziyade, sorduğu araştırma sorusunun hangi yöntem kullanılarak daha iyi cevaplanacağını tespit etme önceliği olduğunu savunan literatürü okuyucuya tanıtmaktır. ${ }^{4}$ Öte yandan, disiplinin gelişimini sağlamış olan metodoloji tartışmaları, aynı zamanda disipline en çok zararı da vermiştir. Pozitivist olmanın sadece sayılarla çalışmak, post-pozitivist olmanın sayıları hiç kullanmamak olarak algılandığı sığ bir akademik ortam, dünya politikasında olanları anlamak ve açıklamak konusunda birbirine değerli dersler verebilecek iki akımı birbirinden uzaklaştırmaktadır.

Dahası, yaşanan çekişmeler Uluslararası İlişkilerin bir disiplin olmadığı düşüncesini de güçlendirmektedir. Pozitivizm ve post-pozitivizm akımlarının iki ucundaki aşırı kutuplaşma sebebiyle bu iki yaklaşım birbirini tamamen reddediyor gözükmektedir. Bu makale, süregelen kutuplaşmanın metot kullanımı üzerindeki etkisini eleştirel ve pragmatik (pragmatic) bir gözle incelemekte; kullanılacak yöntemi, kuram ya da epistemolojiden ziyade sorulan soru ve çalışılmakta olan öznenin özelliklerinin

1 Örneğin, K. W. Thompson, “The Study of International Politics: A Survey of Trends and Developments”, Review of Politics, Cilt 14, No.4, 1952, s.433-467. Morton A. Kaplan, “The New Great Debate: Traditionalism vs. Science in International Relations”, World Politics, Cilt 19, No.1, 1966, s.1-20.

2 Bu söylemler yazarın katıldığı Uluslararası İlişkiler Konseyi (UİK) yıllık toplantılarında ve diğer akademik toplantı ve konferanslarda tekrarlanan temalardır. Bu söylemler Türkiye ile sınırlı değildir. ABD'de ve Avrupa'da katılınan Uluslararası İlişkiler konferanslarında da benzer söylemler yazar tarafından not edilmiştir.

3 Mustafa Aydın, “Uluslararası İlişkilerde Yaklaşım, Teori ve Analiz”, Ankara Üniversitesi Siyasal Bilgiler Fakültesi Dergisi, Cilt 51, No.1, 1996, s.71-114. Oktay Tanrısever, "Yöntem Sorunu: Gelenekselcilik-Davranışsalcılık Tartışması", Atila Eralp (der), Devlet, Sistem ve Kimlik. Uluslararası İlişkilerde Temel Yaklaşımlar, İstanbul, İletişim Yayınları, 2009. Makalede, metot ve yöntem kelimeleri dilin akışını kuvvetlendirmek için dönüşümlü olarak kullanılmaktadır. 
belirlemesi gerektiği fikrini desteklemektedir. Bu noktada, "sorulan soru ve çalışılan özneyi kuram ile epistemolojik ve ontolojik görüşler belirler," şeklinde bir itiraz gelebilir. Söz konusu bakış açısında doğruluk payı olsa da, bu varsayımın kısıtlayıcılığını gevşetme gerekliliği ve faydası, Uluslararası İlişkiler disiplininin bir disiplin olarak varlığını sürdürmesi açısından elzemdir. Daha da önemlisi, disiplinin çeşitliliği ve faydalılığı açısından farklı sorular sorulup bunların farklı yöntemlerle cevaplanması zenginleştirici bir unsur olacaktır. Gerçekçilik ve yeni-gerçekçilik kuramlarının Uluslararası İlişkiler disiplininde on yıllarca devam eden hegemonyası olmasa, bu kuramların sormadığı soruların 1990'lardan itibaren kuvvetlenen inşacı ve eleştirel kuramlar aracılığıyla sorulması ve cevaplanması belki de mümkün olmayacaktı. Benzer şekilde, idealizmin hayal kırıklığına uğratan etkisi gerçekçiliğin yaygınlığını arttırmış, fakat hiçbir kuram tamamen ortadan kalkmamıştır; kuramlar kendilerini sonradan gelenin sayesinde geliştirmişler ya da etkinlikleri azalsa da varlıklarını sürdürmüşlerdir. Diğer bir deyişle, bu makale farklı kuram ve metotların birbirlerini yok etmek yerine, birbirlerinin eksikliklerini tamamlayabileceğini savunan uluslararası yazına katılmaktadır.

Makale temelde, Türkiye'deki Uluslararası İlişkiler yazınında fazla yer almayan, Ruda Sil ve Peter J. Katzenstein'ın 2010'da kendilerini belli bir paradigmanın boyunduruğu altında hissetmekten bunalarak ortaya attıkları "analitik uzlaştırmacılık" (analytic eclecticism) fikrinden yola çıkmaktadır. ${ }^{5}$ Zaten Katzenstein ontolojik, epistemolojik ve metodolojik anlaşmazlıklar farklı dünya görüşlerinden doğdukları için bunları çözümlemeye çalışmanın vakit kaybı olduğunu uzun zaman önce söylemişti. ${ }^{6}$ Smith, pozitivizm ile post-pozitivizm arasında bir uzlaşı mümkün olmadığı için, ikisi arasında bir seçim yapmak gerektiğini söylerken, ${ }^{7}$ Katzenstein anlaşmazlıkların tamamen çözümlenmesi mümkün olmasa da, uzlaşılabilecek konular olduğunda ısrar etmişti. İnşacı (constructivist) olarak tanımlanabilecek kuramsal bir bakış açısına sahip Katzenstein ve diğerleri, hem pozitivist hem de post-pozitivistler tarafından eleştirilseler de, orta yolun bulunabileceği, en azından sorduğumuz soruların her şeyin önünde gelmesi gerektiği konusunda hemfikirdirler. ${ }^{8}$ Bu makale de, bu fikre katılarak analitik uzlaştırmacı bir yaklaşımla kuramı değil, yöntem konusunu irdelemektedir.

Makalenin geri kalanında bu amaçla önce konu ile doğrudan ilgili olan ve zaman zaman yanlış anlaşılan terim ve kavramlar kısaca açıklanacak, daha sonra disiplindeki kuram, epistemoloji ve metodoloji ile ilgili birbirine geçmiş tartışmalar özetlenecektir. Ardından metot kullanımının aslında bu tartışmalardan neden ve nasıl ayrıştırılması gerektiği Sil ve Katzenstein’in analitik uzlaştırmacılık yaklaşımı ışığında ve terörizm çalışmalarından örnekler eşliğinde kısaca anlatılacaktır.

\section{Metodoloji Tartışmaları ve Kullanılan Temel Terim ve Kavramlar}

En basit anlamıyla metodoloji, araştırmacının sorduğu soruya cevap bulabilmek için yaptığı seçimlerdir. Metodoloji, sorulacak sorunun ne olduğu ve nasıl sorulması gerektiği açısından ontoloji ve epistemoloji kavramları ile de yakından ilişkilidir. Epistemoloji, bilgi ve bilmekle ilgilidir; bilgiye na-

5 Rudra Sil ve Peter J. Katzenstein, Beyond Paradigms. Analytic Eclecticism in the Study of World Politics, NY, Palgrave Macmillan, 2010. Kavram analitik uzlaştırmacılık olarak çevrilmiştir, fakat analitik seçicilik olarak da çevrilebilir. Yazar Sil ve Katzenstein'in çalışmalarında seçicilik uzlaştırmacılık hedefini gözettiğinden terimi bu şekilde çevirmeyi tercih etmiştir.

6 Peter J. Katzenstein vd., “The Role of Theory in Comparative Politics: A Symposium”, World Politics, Cilt 48, No.1, 1995, s.1-49.

7 Steve Smith, "New Approaches to International Theory", John Baylis ve Steve Smith (der.), The Globalization of World Politics, Oxford, Oxford University Press, 1997, s.165-190.

8 Örneğin, Jörg Friedrichs ve Friedrich Kratochwil, "On Acting and Knowing: How Pragmatism Can Advance International Relations Research and Methodology”, International Organization, Cilt 63, No.4, 2009, s.701-731. 
sıl ulaşılabileceği ya da neyin bilinebileceği üzerine tartışmaları içerir. Örneğin, araştırmamızı sosyal bilimlerde nesnel bir bilginin var olduğu varsayımı üzerine kurup, araştırma sorumuzu bu varsayıma dayandırarak mı soruyoruz? Gerçekçi veya yeni-gerçekçi kuramsal gelenekten gelenler gibi "Uluslararası İlişkileri sistemin özellikleri ya da ülkelerin maddi kapasiteleri belirler” demek, nesnel bilginin var olduğunu varsaymak ve gözlemlenebilir devlet özelliklerini (mesela gayrı safi milli hâsıla, nükleer başlık sayısı ya da tank sayısı) ölçerek bilgi üretmeye çalışmak, nesnel (bilimsel) bir bilgi arayışına işaret eder. Pozitivist bilim felsefesi bu noktada bilimsel bilginin genellenebilir olduğu, yani her bağlamda ve örnekte geçerli olacağı ve araştırmacının öznel kimliği, amaçları ya da geçmişinin ortaya koyduğu bilgiden bağımsız olduğu varsayımından hareket eder. ${ }^{9}$ Bu varsayım, nesnel bilginin varlığına inanan sosyal bilimcinin olguları, tarihsel derinliğinden ziyade nedensellik ilişkileri içinde incelemesini getirmiştir. Yani nedenselliği anlamak için pek çok örneği birbiriyle karşılaştırmak ve referans olarak da tarihsel süreçleri değil, değişkenlerin gözlem noktalarındaki değişimini almak geleneği oluşmuştur. Burada sosyal bilimci için hedef, evrensel kanunlara ulaşmak olmasa da, mümkün olduğunca genellenebilir ve nesnel bilgiye ulaşmaktır. Öyle ki, bilgi “orada”dır, tek yapılması gereken ona ampirik yöntemler kullanarak ulaşmaktır.

Ampirik (empirical) terimi, sözlük anlamıyla deneye dayalı, deneysel demektir. ${ }^{10}$ Bilimsel bilgi elde etmek için ampirik çalışmalar yapılır ve kuramların bu şekilde test edilmesi esastır. Kenneth Waltz'un bir kuramın bilimsel olup olmadığını anlamak için kullandığı sadelik (parsimony) ölçütü ise, az değişken ile çok şey anlatmaya çalışmak anlamında kullanılmaktadır. ${ }^{11}$ Pozitivist bakış açısına göre, yapılan gözlemler sonucu değişkenler arasında var olduğu düşünülen ilişki, yönü ve kuvveti açıcça belirtilerek bir önerme haline getirilir, yani hipotez kurulur. Ardından da bu hipotezin çeşitli yöntemler ile test edilerek yanlışlanması ya da doğrulanması gerekir. Pozitivistler, karmaşık olan gerçekliği basitleştirerek, değişkenler arası ilişkileri açıklamaya odaklandıkları için nesnel bir gerçeklik varsayımından yola çıkmak durumundadırlar. İlişkilerin genel geçer olması için de mümkün olduğunca çok örnek ile test edilmelerini benimsemişlerdir. Bunun içinse somut değişkenlerin elden geldiğince doğru bir şekilde göstergeler aracılığıyla ölçülmesi gerekmektedir. Bu sebeple veri toplamak için arzu edilen esas yöntem nicel çalışmadır. Örneğin, bir ülkedeki insanların ekonomik sorunlarının o ülkede iç savaş çıkma ihtimalini artırıp artırmadığını test etmek için ekonomik sorunlar gayrı safi milli hasılanın düşüklügüne, iç savaş ise ülkede devlet ve bir grup insan arasında süregelen silahlı çatışmalarda ölenlerin sayısına bağlanarak, bağlantı sayısal verilerin istatistiksel yöntemlerle ölçülmesiyle ortaya çıkartılmaya çalışılabilir. Tabii her korelasyon nedenselliğe işaret etmediğinden kuramın mümkün olduğunca mantıksal bir şekilde kurulması gerekmektedir; bunun için de oyun kuramı veya beklenen fayda kuramı gibi formel (matematiksel) yöntemler kullanılmaktadır.

Sayısal verinin toplanmasının ya da kuramın formel yollardan kurulmasının her zaman mümkün olmadığını kabul eden pozitivist sosyal bilimciler, nitel vaka analizlerinin de bilimsel sürece dikkat edildiği ölçüde sağlıklı sonuç vereceği konusunda hemfikirdirler. ${ }^{12}$ Özetle, hedef bir olguyu açıklamak olduğundan istatistik yöntemi kullanarak genel eğilimler açıklanır, ortalamaya uymayan aykırı değerler (outlier) ise, tekli olay çalışmalarıyla daha iyi anlaşılmaya çalışılır. Kullanılan her yöntemde amaç araştırmacının mümkün olduğunca nesnel olması, veriyi önyargısız toplaması ve değerlendirmesidir.

9 Aydın, Uluslararası Ilişkilerde Yaklaşım, Teori ve Analiz, s.78.

10 Türk Dil Kurumu Sözlü̆ü̈, http://www.tdk.gov.tr/index.php?option=com_gts\&arama=gts\&guid= TDK. GTS.548a7600bd9382.74012678, (Erişim Tarihi: 12 Aralık 2014).

11 Kenneth N. Waltz, The Theory of International Politics, Massachusetts, Addison-Wesley, 1979.

12 Arend Lijphart, "Comparative Politics and the Comparative Method”, The American Political Science Review, Cilt 65, No.3, 1971, s.682-693. 
Böylece aynı veri bir başkası tarafından aynı yöntemler kullanılarak toplanırsa sonuç değişmeyecek, yorum da benzer olacaktır. ${ }^{13}$ Bu noktada doğa bilimlerinin bilimsel bilgi biriktirme çabasına öykünüldüğü açıktır.

Araştırmanın başında karar verilen araştırma düzeyi ise araştırmanın odak noktasının nerede olduğu sorusuyla ilgilidir. Araştırmacı, "analizini oturtacağı temeller ve analizini sürdüreceği düzey hakkında bazı seçimler yapmak zorundadır." ${ }^{14}$ Örneğin, mikro ve makro ya da sistem seviyesi veya birey düzeyi gibi araştırma düzeyleri bulunmaktadır. ${ }^{15}$ Nuri Yurdusev'e göre sıklıkla karıştırılan konulardan biri, analiz seviyesi (level) ve analiz birimidir (unit). ${ }^{16}$ Örneğin yeni-gerçekçilerin kullandığı analiz seviyesi sistemken, analiz birimi devlet olabilir. Ya da karar verme yaklaşımı kullananların yaptığı gibi, hem analiz seviyesi hem de analiz birimi birey olabilir. Önemli olan bunlara araştırmanın başında kuramsal bakış açısının da yardımıyla karar vermek ve çalışma boyunca tutarlı bir analiz yürütmektir. Nitekim analiz nesnelerinin tanımları, araştırmacıların sorgulamadan kabullendikleri varsayımlarını yansıtır. Her araştırmacının yaklaşımından doğan belli varsayımları vardır ve bunlara göre araştırmacı hangi düzeyde hangi aktörlere, olaylara ve süreçlere bakacağına karar verir.

Pozitivist yaklaşımda bilgi nesnel olduğundan analiz nesnelerinin (örneğin, devletler veya uluslararası organizasyonlar) araştırmacıdan bağımsız olduğu varsayımı yapılırken, post-pozitivist bilim felsefesine göre, analiz nesnelerini araştırmacıdan bağımsız görmek gerçekçi bir yaklaşım değildir. ${ }^{17}$ İnsanın bir kültürün parçası olmadığı bir durum bulunmadığından, bir başkasının kültürünü çalışırken önyargılı olmaması ya da kendisiyle çalıştığı kültür ve insanlar arasına mesafe koyabilmesi zor görülmektedir. Bu açıdan, araştırmacılar "kuramlarını ve bulgularını düşünür ve tanımlarlarken içinde yaşadıkları ve parçası oldukları toplum tarafından anlamlandırılan kelime, benzeşim ve eğretilemeleri kullanırlar. Yani sosyal bilimciler analizini yaptıkları nesnenin parçasıdırlar." ${ }^{18}$ Feminist çalışmalarıyla bilinen Ann Tickner’a göre sosyal bilimler, hipotezler oluşturup, bunları kanıtlarla test etmek ve yanlışlamak ya da doğrulamak ihtiyacı üzerine kurulmuştur. ${ }^{19} \mathrm{Bu}$ sebeple de nesnel bilgi ve nedensellik arayışına inanmayan, araştırmacının mesafeliliğini de eleştiren Tickner, tüm feminist çalışmaları olmasa da, kendi alanını sosyal bilim dışında bir mecrada görmektedir.

Post-pozitivist felsefeye göre, öncelikle Uluslararası İlişkiler kendi yöntemlerini mi yaratmalı, yoksa doğa bilimleri ve sosyal bilimlerin yöntemlerinden mi faydalanmalı sorusunun yanıtlanması kaçınılmazdır. Metodoloji ve epistemoloji açısından önemli başka sorular da cevaplanmayı beklemektedir: Sosyal bilimlerde çalışılan devlet, toplum, ekonomi, ideoloji ya da demokrasi gibi nesneler gerçekte var mı; yoksa bunlar insanların var olduğuna inandığı kendi yaratımları mı? Çalışılanlar laboratuvarda gözlemlenebilir nesneler değillerse bunları anlamak için kullanılacak yöntemler aynı olabilir mi? Özellikle Uluslararası İlişkilerin nesneleri, davranışlarını karmaşık sebeplerle, çoğu zaman da döngüsel olarak gerçekleştirdiklerinden bilgiye doğrusal bir nedensellik anlayışıla yaklaşılabilir

13 Ibid.

14 Aydın, Uluslararası İlişkilerde Yaklaşım, Teori ve Analiz, s.74.

15 J. David Singer, “Uluslararası Iliş,kilerde Analiz Düzeyi Meselesi”, Uluslararası Ilişkiler, Cilt 3, Sayı 11, Güz 2006 , s.3-24.

16 Nuri Yurdusev, “'Analiz Seviyesi’ ve ‘Analiz Birimi’: Bir Ayrım Argümanı”, Uluslararası Ilişkiler, Cilt 4, Sayı 16, 2007-2008, s.3-19.

17 Yoshiko M. Herrera ve Bear F. Braumoeller, “Symposium: Discourse and Content Analysis”, Qualitative Methods, Newsletter of the American Political Science Association Organized Section on Qualitative Methods, 2004, p.17.

18 Nil Şatana, "Sosyal Bilimlerde Karşılaşılacak Zorlukların Üstesinden Gelmek: Yöntemsel Zorluklar” http://www. acikders.org.tr/course/view.php?id=128 (Erişim Tarihi: 30 Mayıs 2013).

19 J. Ann Tickner, "Feminism Meets International Relations: Some Methodological Issues”, Brooke Ackerly, Maria Stern ve Jacqui True (der.), Feminist Methodologies in International Relations, Cambridge University Press, 2006, s.19. 
mi? Olgulara dair birçok benzer durumu açıklamak ve genellemek için derinlik içermeyen açılamalar yapmak mı daha makbuldür, yoksa tek bir durumu tüm karmaşıklı̆ı̆yla ve derinlemesine anlamak $\mathrm{m}$ ? Bu ve benzeri soruları soran post-pozitivist araştırmacılar, özne-nesne sorunu olarak niteledikleri, araştırmacının özne, çalışılanın nesne olduğu bir yaklaşımı reddederler. Çünkü özne ve nesnenin birbirlerinden keskin bir çizgiyle ayrılabileceğine inanmazlar. Bu anlayışa göre, "sosyal bilimlerde elde etmeye çalıştığımız bilginin hem özne hem de nesnesiyizdir. Toplumsal hayatı çalıştığımızda ise aslında kendimizi çalışırız."20

Epistemolojik açıdan fikir ayrılığı yaşayan pozitivist ve post-pozitivist araştırmacılar için ontoloji de ayrışma kaynağıdır. Daha önce de belirtildiği üzere, Uluslararası İlişkilerde neyin nesnel olarak var olduğu, neyin insanın ya da toplumun yaratımı olduğu konusu sıklıkla tartışılmıştır. Pozitivistlerin duyularla varlığı doğrulanan nesnelerin çalışılması felsefesini Uluslararası İlişkiler gibi sosyal araştırmalar için yalnızca kısıtlayıcı değil, aynı zamanda hatalı bulanlar çoktur. ${ }^{21}$ Öyle ki, Hollis ve Smith gibi yazarların ontolojiyi felsefi olarak algılamayıp, dünyayı anlamak ve açıklamak arasındaki farkı bilimsel ontoloji ile açıklaması ve aslında pozitivistlerin var olduğuna inanıp açıkladığı olgular ile post-pozitivistlerin var olduğuna (veya olmadığına) inandığı olgu ve nesnelerin (yani dünyanın) aynı olmadığı savı çok eleştirilmiştir. ${ }^{22}$ Sonuçta, pozitivist ve post-pozitivist felsefelere göre çalışılan nesne dünya politikasıken, sorulan sorular, odaklanılan olgular, verilen cevaplar ile bulguları anlama ve anlamlandırma şekilleri değişmektedir. Bu sebeple de metodoloji ve kullanılan metotlar üzerine neredeyse bir asırdır süregelen tartışmalar bu bölümde özetlenen terim ve kavramlardan tamamen ayrıştırılamaz. Bir sonraki bölümde bu tartışmalar ele alınacak, ardından da bir uzlaşma noktasının bulunup bulunmadığı sorgulanacaktır.

\section{Uluslararası İlişkilerde Metodoloji Tartışmaları}

Yukarıda tanımlanan kavramlar üzerinden yapılan ve zaman zaman keskinleşen tartışmalar, yıllarca Uluslararası İlişkilerin "bölünmüş bir disiplin” olup olmadığını sorgulatmıştır. ${ }^{23}$ Öyle ki, Barry Buzan ve Richard Little, 2001'de yazdıkları bir makalede Uluslararası İlişkiler disiplininin gidişatından son derece hoşnutsuz olduklarını belirterek, dışarıdan bakanlara disiplinin "bölünmüş, yönsüz ve kavgacı" gözüktüğ̈üü vurgulamışlardır. ${ }^{24}$

Öte yandan, Colin ve Miriam Elman bir çalışmalarında, Macar filozof Imre Lakatos'un kriterlerini kullanarak, Uluslararası İlişkiler disiplininde gelişme olup olmadığını irdelemişlerdir. ${ }^{25}$ Lakatos’a göre, bir disiplinin bilimselliği için kuramsal ve ampirik tüm gelişmelerin ileri götürücü (progressive) ve tutarlı olması gerekmektedir. Elman'lar, bilimsel çalışmaların aynı zamanda meta-teori ya da felsefe ile ilgilenmesinde bir sakınca olmadığını, bilim felsefesini ya da kullanılan metotları tartışmanın bir disiplini bozmayacağını, aksine sorun kayması (problem shift) yaşanmasının bir disiplini ileri götüre-

20 Nil Şatana, "Sosyal Bilimlerde Karşılaşılacak Zorlukların Üstesinden Gelmek”.

21 Örnek için bkz. Alexander E. Wendt, “The Agent-Structure Problem in International Relations Theory”, International Organization, Cilt 41, No.3, 1987, s.351.

22 Patrick Thaddeus Jackson, The Conduct of Inquiry in International Relations: Philosophy of Science and Its Implications for the Study of World Politics, Oxon, Routledge, 2011, s.28.

23 Karl J. Holsti,, The Dividing Discipline: Hegemony and Diversity in International Theory. Boston, MA, Allen \& Unwin, 1985.

24 Barry Buzan ve Richard Little, "Why International Relations Has Failed As An Academic Project and What to Do About It”, Millennium: Journal of International Studies, Cilt 30, No.1, 2001, s.32.

25 Colin Elman ve Miriam Fendius Elman, (der.), "Lessons from Lakatos”, Progress in International Relations Theory, Cambridge, Harvard University Press, 2003, s.21-68. 
ceğini iddia etmişlerdir. ${ }^{26}$ Bu makalede de, disiplindeki kuramsal ve metodolojik çeşitliliğin zenginlik olduğu fikri savunulmaktadır.

Uluslararası İlişkilerin bir disiplin olmaktan uzaklaşıp uzaklaşmadığının irdelenmesinin en önemli sebebi 1930’lardan günümüze süregelen dört büyük tartışmadır. Ole Wæver'e göre, önce realist ve idealistler (liberaller) Uluslararası İlişkilerde sadece analiz mi yapmalı, yoksa yapılması gerekene dair kurallar da mı koymalı konusunda fikir ayrılığı yaşarlarken; daha sonra davranışsalcılar ve gelenekselciler Uluslararası İlişkilerin ne kadar nesnel ve bilimsel çalışılabileceğini tartışmışlardır. ${ }^{27}$ Üçüncü tartışmada yeni-gerçekçi, yeni-liberal ve yeni-Marksist kuramcılar sosyal dünyayı anlamak ile açıklamak üzerine ontolojik bir tartışma ve araştırmanın hangi düzeyde yapılması gerektiğine dair metodolojik bir tartışmaya odaklanmışlardır. Son olarak, akılcılar, inşacılar ve post-modernistler ontoloji, epistemoloji ve metodoloji üzerine büyük fikir ayrılıkları yaşadıkları bir tartışma içine girmişlerdir. Bu makale, Wæver'ın bu dört büyük tartışma yaklaşımını temelde benimsese de, odağı metodoloji ve metot üzerinde tutmak için son tartışmayı pozitivizm/post-pozitivizm olarak ayırmaktadır. Her ne kadar epistemoloji ve metodoloji konusunda daha pozitivist bir yaklaşıma sahip inşacılar bulunsa da, ${ }^{28}$ makale genel uygulamayı takip ederek inşacılığı post-pozitivizmin altında, eleştirel kuram ve post-modernizm ile beraber sınıflandıracaktır.

\section{Birinci ve Üçüncü Tartışmalarda Metodun Yeri}

Uluslararası İlişkiler disiplininde 1930-40’larda yaşanan ve birinci büyük tartışma olarak adlandırılan gerçekçilik/idealizm (liberalizm) tartışmasının öznesi, metot ya da bilim felsefesi değil kuramdı. Dönemin uluslararası politika alanındaki önemli isimleri, temelde gerçekçilik ve idealizm kuramlarının kavramları, varsayımları ve hipotezleri arasındaki farklılıkları ele almışlar; iki kuramın metodolojideki farklı uygulamaları ise tartışmada nispeten önemsiz bir ayrıntı olarak kalmıştır. Yine de en önemli metodolojik fark gerçekçilerin idealistleri çalışmalarında olanın yanı sıra, olması gerekeni de ele aldıkları için eleştirmiş olmalarıdır. ${ }^{29}$

Nitekim, Milletler Cemiyeti’nin başarısızlı̆̆ı ve Birinci Dünya Savaşı’nın patlaması idealistlerin varsayımlarının ve hipotezlerinin yeteri kadar bilimsel olmadığı kanısını desteklemiş, normatif çalışmaların Uluslararası İlişkilerin çalışılmasında doğru öngörüler getirmediğini düşündürmüştür. Gerçekçiler, yukarıda anlatıldığı tanımıyla bilimsel çalışmalar yapmış olmasalar da, normatif yargılardan uzaklaştıkları için liberallerden daha bilimsel çalışmalar yaptıklarını düşünmüşlerdir. Buna en güzel örnek, kendisi aslen bir sosyal bilimci değil tarihçi olan E. H. Carr’ın, "ütopyacı idealistleri, arzuları gerçeklerle karıştırdıkları iddiasıyla eleştirerek, gerçek bilimin ilk önce olguların aslında nasıl olduklarını anlamaya çalışmak” ile yapılacağını iddia etmesidir. ${ }^{30}$ Ayrıca “Carr’’n ardından giden diğer

26 Ibid.

27 Ole Waever, "Four Meanings of International Society: A Transatlantic Dialogue", B.A. Roberson (der.), International Society and the Development of International Relations Theory, Londra, Pinter, 1998.

Tartışmaların sayısı yazara göre değişse de, içerik genelde aynıdır. Tartışmalar üzerine daha detaylı bilgi için bkz.: Steve Smith, Ken Booth ve Marysia Zalewski $\square$, International Theory: Positivism and Beyond, Cambridge, Cambridge University Press, 1996. Tartışmanın Türkçe bir analizi için: Erdem Özlük, "Gelenekselcilik-Davranışsalcılık Tartışmasını Bağlamında Anlamak”, Ankara Üniversitesi SBF Dergisi, Cilt 64, No.3, 2009, s.197-220.

28 Örnekler için bkz. Jeffrey Checkel, “Social Constructivisms in Global and European Politics: A Review Essay”, Review of International Studies, Cilt 30, No.2, 1998, s.229-44. Ted Hopf, “The Promise of Constructivism in International Relations Theory”, International Security, Cilt 23, No.1, 1998, s.171-200.

29 Martin Griffiths, Realism, Idealism and International Politics: A Reinterpretation, Londra, Routledge, 1992.

30 Mustafa Aydın, "Uluslararası İlişkilerin ‘Gerçekçi’ Teorisi: Kökeni, Kapsamı, Kritiği”, Uluslararası İlişkiler, Cilt 1, Sayı 1, 2004, s.33-60. 
realistler, örneğin Hans Morgenthau, uluslararası politika biliminin sadece tarihsel ve normatif değil, fakat genel ve teorik olması gerektiğini de vurguladılar." ${ }^{1}$ Tartışma, idealizmin aleyhine sonuçlanmış, sonraki on yıllarda gerçekçiler ve İkinci Dünya Savaşı sonrasında ise yeni-gerçekçilik dünya politikası$\mathrm{n} ı$ açıklamakta yaygın kuramlar haline gelmişlerdir.

İşin ilginci, daha sonra Morgenthau’nun da, özellikle kavramsallaştırılması ve ölçülmesi sorunlu görülen güç ve insan doğası kavramları sebebiyle Kenneth Waltz gibi yeni-gerçekçiler tarafindan sert biçimde eleştirilerek, yeteri kadar bilimsel bulunmamasıdır. ${ }^{32}$ Yine de, gerçekçi ve liberaller arasında süregelen bu sınırlı metodolojik tartışmanın, 1950'lerde başlayan gelenekselcilik/davranışsalcılık tartışmasında iki kuramın birbiriyle metodolojik bir müttefiklik kurana kadar devam ettiği söylenebilir. ${ }^{33}$

Öte yandan, üçüncü tartışma olarak da bilinen yeni-gerçekçilik, yeni-liberalizm ve yeni-Marksizm arasındaki tartışma bazılarına göre dördüncünün ön provasıdır. Nitekim Lapid 1989'da postpositivizmin tanımlamasını yaparak tartışmanın önünü açmıştı. ${ }^{34}$ Yeni-Marksizmin sosyal bilimlere ve bilimsel metoda yaklaşımı yeni-gerçekçi ve yeni-liberal kuramlarınkinden tamamen farklıdır. YeniMarksistler bilime ve özellikle de sosyal bilimlere inansalar da, gerçekçilik ve liberalizm gibi büyük kuramları ve bunların ortaya çıkış sürecini onaylamazlar. Örneğin kuramın önemli isimlerinden Amerikalı sosyolog Charles Wright Mills, 1959'da yazdığı kitabında sosyal bilimlerin soyut ampirisizm ve büyük kuramdan ibaret kaldığını ve tarihsel gerçeklikten koptuğunu iddia etmiştir. ${ }^{35}$ Sosyal bilimleri formel veya nicel yöntemler ya da büyük kuramlar ile çalışmayan, vaka incelemesi gibi nitel yöntemler kullanan sosyal bilimciler ise, yeni-Marksistlerin bu eleştirilerini sadece bir polemik yaratma çabası olarak görmüşlerdir. ${ }^{36}$ Tartışmanın metot açısından gelişimi, aşağıda pozitivizm/post-pozitivizm tartışması bölümünde detaylandırılacaktır.

\section{Gelenekselcilik/Davranışsalcılık Tartışmasında Metodun Yeri}

Metot üzerine Siyaset Bilimi ve Uluslararası İlişkilerde yaşanan ilk gerçek tartışma ya da disiplinde kabul gördüğü adıyla "ikinci büyük tartışma”, gelenekselcilik ve davranışsalcılık akımları arasında 19501970 yılları arasında yaşanmış; en hareketli dönem ise 1960'larda geçirilmiştir. Tartışmanın önemi, davranışsalcılığın pozitivizme evrilmesi ve pozitivizme duyulan tepkinin artmasıla beraber çıan ve dördüncü büyük tartışma olarak adlandırılan pozitivizm/post-pozitivizm tartışmasının temelini oluşturmasıdır. Fakat ikinci büyük tartışma, dördüncüden farklı olarak epistemolojiden ziyade metodolojiye odaklanmıştır. ${ }^{37}$

31 Ibid.

32 Sil ve Katzenstein'ın yer verdiği (s.52) Morgenthau'nun nicel yöntemlerden başka metot kullanmayan pozitivistlere olan eleştirileri için: Hans J. Morgenthau, "Common Sense and Theories” H.J. Morgenthau (der), Truth and Power: Essays of a Decade 1960-1970, NY, Praeger, 1970, s.241-248.

33 Burada önemli bir konuya dikkat çekmek gerekmektedir. Liberalizm içinde geleneksel metotlarla çalışanlar da bulunmaktadır. Yani tüm liberal araştırmacılar aynı anda davranışçılık akımından etkilenmiş değillerdir. Hala liberal kuram çerçevesinde ama daha normatif ve pozitivizmi benimsememiş çalışmalar da bulunmaktadır. Aynı durum gerçekçiler için de geçerlidir. Bu iki kuramın bir sentezini yapmaya çalışan İngiliz Okulu'nun bu ve bir sonraki tartışmadaki yeri ise aşağıda ele alınacaktır.

34 Yosef Lapid, “The Third Debate: On the Prospects of International Theory in a Post-Positivist Era”, International Studies Quarterly, Cilt 33, No.3, 1989, s.235-254.

35 C. Wright Mills, The Sociological Imagination, New York, Oxford University Press, 1959.

36 Lewis S. Feuer, “A Neo-Marxist Conception of Social Science”, Ethics, Cilt 70, No.3, 1960, s.237-240.

37 Bilgehan Emeklier, "Uluslararası İlişkiler Disiplininde Epistemolojik Paradigma Tartışmaları: Postpozitivist Kuramlar”, Bilge Strateji, Cilt 3, No.4, 2011, s.139-184, s.140. 
Disiplinin kurucuları ve birinci tartışmanın kahramanları genelde tarihçiler, hukukçular ya da eski diplomatlar olduklarından yaklaşımları daha çok tarih, hukuk ve felsefeden etkilenmişti. ${ }^{38} \mathrm{Bu}$ sebeple olandan ziyade olması gerekeni (normatif) çalıştıklarından ve ahlaki yargıları ön plana çıkardıklarından gelenekselciler (klasikler) olarak tanımlanmışlardır. Fakat İkinci Dünya Savaşı süresince daha çok klasik yöntemler ile çalışılan uluslararası politika, savaş sonrasında matematik, doğa bilimleri, ekonomi ve siyaset biliminden etkilenmiştir. Geride kalan iki büyük savaşa bakarak tarih ve hukuk gibi disiplinlerin dünya politikasını anlamakta ve çözümlemekte yeterli olmadıkları, doğa ve sosyal bilimlerinin daha faydalı olacağına dair bir kamuoyu oluşmuştur. Bu özellikle ABD'de ortaya çıkan bir gelişmeydi. Ne zaman bir araştırma alanına devletler destek verse, o alanda ilerlemek isteyenlerin sayısında da artış olduğundan, davranışsalcılık da aynı şekilde gelişmiştir. Hem gerçekçi hem de liberaller, dünya politikasında öngöremedikleri ya da açıklayamadıkları gelişmeleri, faydalandıkları kuramın eksikliklerinde değil, kullandıkları yöntemlerin yeteri kadar bilimsel olmamasında aramışlardır. Klasik ya da gelenekselci nitel yöntemlerin günah keçisi olması da işte bu sebebe bağlanabilir.

Davranışsalcıların en önemli amacı, normatif ya da yargılara dayanan tahminler yapmak yerine, davranışların gözlemlenerek değişkenler arasında hipotezler kurulması, verilerin toplanması ile kurulan hipotezlerin gözlemlenebilir olgulardan toplanan veriler kullanılarak nicel ya da nitel yöntemlerle ölçülerek test edilmesidir. ${ }^{39}$ Böylelikle yanlışlanan hipotezler bilimsel bilgi birikiminden elenecek ve Uluslararası İlişkiler daha bilimsel bir disiplin olarak rüştünü ispatlayabilecekti.

Davranışsalcılık sadece gözlemlenebilen olgulara odaklandığından davranışçı araştırmacıların sordukları sorular da gelenekselcilerinkinden farklı olmuştur. Örneğin, davranışsalcılar savaşı ortaya ç1karan etmenleri irdelerken, devletlerin güç mücadelesinin savaşa sebep olduğu hipotezinden yola çıkmışlarsa, bu hipotezi test etmek için her devletin sahip olduğu silah ve nükleer başlık sayısının ölçülmesi gerektiği sonucuna varmışlardır. Gelenekselciler ise, uluslarararası hukuk savaşı ne şekilde önleyebilir sorusundan yola çıktığından davranışsalcılarla aynı yöntemi izlemek zorunda kalmamış, normatif ve yargısal çalışmalar yapmaya devam etmişlerdir. Çoğu gelenekselci, Uluslararası İlişkilerin asla tamamen bilimsel olamayacağını, çünkü insanların incelendiği bir disiplinde her zaman için bir öznellik bulunacağını iddia etmişlerdir. ${ }^{40} \mathrm{Bu}$ iki yöntem bir süre çekişmişse de, sonunda gerçekçilik ve liberalizm gibi iki baskın kuramın öncülerinin davranışsalcılığı içselleştirmesiyle özellikle ABD’de bilimsel bulunmayan çalışmalar dergilerde yayınlanmamış; gelenekselci Uluslararası İlişkiler çalışanlar Avrupa dışında bir varlık göstermekte zorlanmışlardır. En azından Soğuk Savaş boyunca bu durum böyle devam etmiştir. Bu arada, ne yazık ki Amerika'da gelenekselciliği reddetmek adına tarihten de uzaklaşılmış, her ne kadar vaka çalışması yöntemi bilimsel kriterlere uygun olarak ve hipotezlerin test edilmesi amacıyla kullanıldıysa da, vaka sayısının artması gerektiğini savunanların baskın hale gelmesiyle vaka incelemeleri tarihsel derinlikten uzaklaşmıştır.

Yine de İngiliz Okulu ya da uluslararası toplum ekolü olarak bilinen ve Hedley Bull'un baş1nı çektiği kuramcılar, gerçekçilik ve liberalizmin birbirini tamamlayan yönlerini bir araya getirmekle kalmayıp, etnografi gibi klasik araştırma yöntemlerini de kullanmaya devam etmişlerdir. ${ }^{41}$ İngiliz Okulu halen hukuk, felsefe ve tarih disiplinlerinden faydalanmakta ve hepsiyle olmasa da bazı postpozitivistlerle ortak bir takım yöntemsel yaklaşımları benimsemektedir. Örneğin, İngiliz Okulu’nda yer alan Hedley Bull ve Martin Wight gibi düşünürler, bilimsel yöntemin nesnel gerçeklik arayışını ka-

38 Robert Jackson ve Georg Sorenson, Introduction to International Relations, New York, Oxford University Press, 1999 , s.45.

39 Erdem Özlük, “Gelenekselcilik-Davranışsalcılık Tartışmasını Bağlamında Anlamak”, s.203.

40 Klaus Knorr ve James N. Rosenau, Contending Approaches to International Politics, Princeton, Princeton University Press, 1969.

41 Hedley Bull, "International Theory: The Case for a Classical Approach”, World Politics, Cilt 18, No.3, 1966, s.361-77. 
bul etmemişler ve normatif olmayan bir Uluslararası İlişkiler çalışmasının, devletlerin ve onları yöneten insanların başrolde olduğu dünya politikasını anlamakta başarılı olamayacağını iddia etmiş̧lerdir. ${ }^{42}$ Bu sebeple de nitel yöntemlerin dışındaki yöntemlere sıcak bakmamışlardır.

Özelde İngiliz Okulu ve genelde gelenekselciler, bilginin yorumlanması ve yansıtılması gerektiğini, bunu da insanın ancak tarih ve kültür bağlamında yapabileceğini iddia etmişlerdir. Bu nedenle de, Uluslararası İlişkilerde araştırmacının bulgularının hiçbir zaman genel geçer yasalarla sonuçlanamayacağını, sosyal araştırmanın kusursuz bir süreç olmadığını ileri sürmüşlerdir. ${ }^{43}$ Benzer şekilde, insanın kendini değerlerinden soyutlayarak dünya politikasını çalışamayacağını iddia etmişlerse de, davranışsalcılarla bu değerlerin araştırmayı etkilememesi için kontrol altında tutulmaları gerekliliği konusunda aynı fikirdedirler. ${ }^{44}$ Ayrıca her ikisi de ideolojinin araştırmaya karıştırılmaması konusunda anlaştıklarından, bu açıdan idealistlere karşı da aynı safta sayılabilirler.

Davranışsalcılar ise, sosyal bilimleri doğa bilimlerinden farklı görmediklerinden ikisinin aynı metotları kullanmasında bir sakınca görmemiş, değişkenlerini nicelikselleştirmek için çaba sarfetmişlerdir. Bu çaba daha sonraları pozitivist gelenekte çalışan realistler tarafından savaş çalışmaları alanında ve liberaller tarafından da demokratik barış yazınında nicel yöntemlerin kullanılarak hipotezlerin test edilmesi şeklinde yaygınlaştırılmıştır. ${ }^{45}$ Stratejik çalışmalar ise, karar alma çalışmalarının etkisinde formel yöntemlerle kuram oluşturulmasından etkilenmiş, formel modellemeler ve akılcı seçim yaklaşımları aktörlerin belli durumlarda çıkarlarını artırıp kayıplarını en aza indirmeyi hedefleyerek karar verdiklerini varsaymıştır. Bu kapsamda, Stratejik Çalışmalar, karar alma süreçlerinin adım adım incelenmesi ile mantıksal tutarlılığı olan kuramlar yarattıkları iddiasındadırlar. ${ }^{46}$ Fakat bu çalışmaların hiçbiri bilimsel bilgi üretmek için sadece nicel yöntemler kullanılmasını şart koşmamışlardır. Öyle ki, bu konuda yanlış anlaşılmaktan sıkılan üç önemli pozitivist isim -ki aralarında yeni-liberal kurumsalc1lığın öncüsü Robert Keohane de bulunmaktadır- 1990’larda bir araya gelerek nitel yöntemlerle de sosyal bilim yapılabileceğine dair klasikleşen bir kitap yazmışlardır. ${ }^{47} \mathrm{Bu}$ yöntem kitabı, post-pozitivistler tarafından çok eleştirilmiş, kitabın Hume'dan Weber'e yaptığı referanslarla sunduğu "sosyal olguların sadece akılcı bir bakış açısıyla hem anlanabilecek, hem de açıklanabilecek ve nedenleri nitel yöntemler sistematik bir şekilde kullanılarak saptanabilecek nesneler oldukları" fikri ne gelenekselciler ne de post-pozitivistler tarafından kabul görmemiştir. ${ }^{48}$

Sonuçta, Morton Kaplan’ın 1966'da gelenekselcilik ve bilim arasındaki “yeni büyük tartışma”ya atfettiği önem son derece isabetlidir. ${ }^{49}$ Oktay Tanrısever'e göre, davranışsalcı okul her şeye rağmen

42 Tim Dunne, Inventing International Society: A History of the English School, New York, St. Martin, 1998.

43 Hedley Bull, Strategic Studies and Its Critics, Australian National University, 1967.

44 Balkan Devlen, Patrick James ve Özgür Özdamar, “The English School, International Relations, and Progress” , International Studies Review, Cilt 7, No.2, 2005, s.171-97.

$45 \mathrm{Bu}$ çalışmalara örnek olarak şu çalışmalar verilebilir: Joseph M. Grieco, "Anarchy and the Limits of Cooperation: A Realist Critique of the Newest Liberal Institutionalism”, International Organization, Cilt 42, No.3, 1988, s.485-507, James Lee Ray, Democracy and International Conflict: An Evaluation of the Democratic Peace Proposition, Columbia, University of South Carolina Press, 1995. David L. Rousseau, vd., "Assessing the Dyadic Nature of the Democratic Peace, 19181988”, American Political Science Review, Cilt 90, No.3, 1996, s.512-533. Michael W. Doyle, Liberal Peace: Selected Essays, New York, Routledge, 2011.

46 Thomas C. Schelling, The Strategy of Conflict, Harvard University Press, 1960. A. Rapaport, Fights, Games, and Debates, Ann Arbor: University of Michigan, 1960.

47 Gary King, Robert O. Keohane ve Sidney Verba, Designing Social Inquiry. Scientific Inference in Qualitative Research, Princeton, Princeton University Press, 1994.

48 King, Keohane, Verba'nın yaklaşımına itirazlar bir özel sayıda toplanmıştır: “The Qualitative-Quantitative Disputation”, American Political Science Review, Cilt 89, No.2, 1995.

49 Kaplan, “The New Great Debate”, s.3. 
"ulus-devlet üstü ve ulus-devlet altında, yeni çözümleme düzeylerinin olanaklı olduğunu ortaya koymuş”; düzey ve birimi zaman zaman birbirine karıştırsa da, bu tartışma sayesinde Uluslararası İlişkilerde yeni inceleme konuları ve araştırma soruları ortaya çıkabilmiştir. ${ }^{50}$ Davranışsalcıların etkisi halen pozitivist sosyal bilimlerde görülmektedir. Nitekim entegrasyon çalışmalarında Karl Deutsch'un savları geçerliliğini korurken, savaş çalışmalarında David Singer'ın 1960'larda toplamaya başladığı "Savaşın Bağıntıları" (Correlates of War) veritabanı halen yaygın olarak kullanılmaktadır. ${ }^{51}$

Sonuçta, Amerikalı siyaset bilimciler davranışsalcılığı bir bilimsel devrim olarak nitelerlerken, Tim Dunne gibi Avrupalı araştırmacılar bunun bir devrim olmadığını, ABD’nin başını çektiği ideolojik bir duruşun gerekliliği olduğunu öne sürmüşlerdir. ${ }^{52} \mathrm{Bu}$ sebeple de, davranışsalcılığın getirdiği metotları çözüm odaklı kuramların çözüm odaklı yöntemleri olarak nitelemişler, hatta sosyal bilimlerden insanı ve insani değerleri çıkarmaya çalışmakla suçlamışlardır. ${ }^{53}$ Muhafazakâr olmakla itham edilen davranışsalcıların ise kendilerini devrimci görmeleri bu iki bakış açısının uzlaşmazlığını vurgulaması açısından ilginçtir. Bu uzlaşmazlık bir sonraki bölümde anlatılacak dördüncü tartışmada kendini iyice belli edecektir.

\section{Pozitivizm/Post-Pozitivizm Tartışmasında Metodun Yeri}

Pozitivizm/post-pozitivizm tartışması dördüncü tartışma olarak da bilinmektedir ve yaygın kanının aksine temelde bir metodoloji tartışması değil, epistemoloji ve ontoloji uzlaşmazlığıdır. Her ne kadar gelenekselciler 1950'lerde davranış̧̧ılara karşı fazla varlık gösterememişlerse de, post-pozitivist Uluslararası İlişkiler kuramları, Soğuk Savaşın bitimiyle ortaya çıkan yeni soru ve sorunların mevcut kuramların ışığında anlaşılamayacağını saptayarak, davranışsalcılıktan pozitivizme evrilenlere, özellikle de Kenneth Waltz öncülügünde iki kutuplu bir dünyanın sorunlarını çözmek amacıyla geliştirilen yeni-gerçekçiliğe karşı savlar geliştirmişlerdir. Yeni-gerçekçi kuramın az değişkenle çok şey anlatmayı benimseyen sadeci felsefesi Uluslararası İlişkileri uluslararası sistemin yapısının sonuçlarına bağlamış, süper-güç politikalarını yüksek politika olarak gördügünden savaş ve barışı bu çerçevede anlatmıştır. Bu sebeple de çevrede (periphery) kalan ülkelerin sorunları ve soruları ikincil öneme indirgenmiştir. Buna tepki duyarak gelişen post-pozitivist bilim felsefesiyle çalışanlar, yeni-gerçekçi ve yeni-liberal kuramcıların kullandığı bilimsel yaklaşım ve metotların aradığı bilimsel kanunları yaratmanın imkânsızlığını vurgulamış ve bunların terk edilmesi gerektiğini iddia etmişlerdir. ${ }^{54}$ Üstelik bu sefer pozitivist felsefe ile oluşturulan kuramların Soğuk Savaşın aniden bitişini ve sonrasında ortaya çıkan sorunları açılamaktaki yetersizliği, "açıklamak" yerine "anlamaya” yapılan vurguyu arttırmıştır. Öte yandan post-pozitivistler, değişmesini önerdikleri metotların yerine geçmesi gerekenin ne olduğu konusunda ise anlaşamamışlardır. ${ }^{55}$ Pozitivistler bu nedenle eleştirel kuramları, tutarlı bir kuram olmaktan ziyade bir yaklaşım olmakla itham ederek, ciddiye almamışlardır. ${ }^{56}$

50 Tanrısever, “Yöntem Sorunu”, s. 117, 119. Bölümün tamamında bu tartışma ayrıntısıyla anlatılmıştır.

51 Melvin Small ve J. David Singer, Resort to Arms: International and Civil War,1816-1980, Beverly Hills, CA, Sage, 1982.

52 Karl Deutsch, “The Place of Behavioral Sciences in Graduate Training in International Relations”, Behavioral Science, Cilt 3, No.1, 1958, s.278-284. Timothy Dunne, "Mythology or Methodology? Traditions in International Theory", Review of International Studies, Cilt 19, No.3, 1993, s.305-318.

53 Ibid.

54 Jackson ve Sorenson, Introduction to International Relations, 1999, s.61.

55 Ibid.

56 Jeffrey T. Checkel, “The Constructive Turn in International Relations Theory”, World Politics Cilt 50, No.1, 1998, s.324348 . 
Robert Keohane'in 1988'de bir konferansta eleştirel çalışmaları eleştirerek başlattığı tartışma ivmesini halen kaybetmemiştir. ${ }^{57}$ James Der Derian'a göre ise, Keohane'in özellikle yapısalcılara getirdiği eleştiriler aslında yansıtmacılığı (reflectivism) çok iyi bilmemesinden kaynaklanmaktadır. ${ }^{58}$ Öyle ki, Keohane'e göre yansıtmacılar edilgendir ve herhangi bir hipotez test etmediklerinden aslında tek yaptıkları başkalarının görüşlerini eleştirmektir. Post-yapısalcılar ise dil ve söylemleri çeşitli yöntemlerle inceleyerek, Uluslararası İlişkilerde yaşanan yeni gelişmeleri akılcılardan daha iyi anlamlandırabildiklerini düşünmektedirler. ${ }^{59}$ Nitekim International Studies Quarterly'nin Eylül 1990 sayısının tamamı farklı metotlara kucak açmıştır. Ken Booth ise, 1991'de yayınladı̆̆ı makalesi ile post-pozitivist bir yaklaşımla, eleştirel güvenlik çalışmalarının gerekliliğinden bahsetmiş ve Galler Okulunu kurarak Frankfurt Okulu ve Gramsci'nin eleştirel öğretilerini hem kuramsal hem de yöntemsel anlamda geliştirmeye odaklanmıştır. ${ }^{60}$

Post-pozitivistlerin en önemli çıkış noktaları, pozitivist yazının büyük bir kısmının ABD’den çıkmış olması ve Amerikan bakış açısını yansıtması, bu sebeple de kullandığı metotların dünyanın geri kalanının gerçeklerini anlamakta yetersiz kalabilmesidir. ${ }^{61} \mathrm{Bu}$ açıdan, pozitivist bilim felsefesi ile dünya politikasını çalışan Uluslararası İlişkiler kuramları, "kendi epistemolojilerini ontoloji yerine koyarak monolitik, tarih-ötesi ve asosyal bir uluslararası fikri kurarlar.” ${ }^{62} \mathrm{Bu}$ sebeple post-pozitivistler sadece akademik çalışmalarda süregelmiş pozitivist hegemonyanın epistemoloji ve ontolojisini hatalı bulmakla kalmaz, aynı zamanda bu çalışmaların kendileri kadar gelişmiş olmayan ülkeleri sömürmek ve kontrol etmek üzere başta Amerika olmak üzere Batılı devletler tarafindan kullanıldığını da öne sürerler. ${ }^{63}$ Öyle ki, siyasi değerler sosyal araştırmanın amaç ve niteliğini de değiştirmektedir. Nitekim eleştirel kuramın önemli isimlerinden Robert Cox'un meşhur ifadesiyle, kuram her zaman biri ve bir amaç içindir. ${ }^{64}$ Cox’a göre olguları anlamak yerine açıllamaya çalışan pozitivizm, var olan düzeni değiştirmek yerine, onun sorunlarını en kısa yoldan ve az kayıpla çözmeye çalışır. Bunu yaparken güçlü devletlerin çıkarlarını gözetmeyi hedeflediğinden, pozitivist metodoloji de bu ideolojiyi korumak ve kollamak adına doğa bilimlerini kopyalamış ve aslında nicelikselleştirilemeyecek değişkenleri sayılarla ifade etmeye çalışmıştır. ${ }^{65}$

Öte yandan, akademik araştırmanın özünde politik olduğu ve bu sebeple asla nesnel bir bilgi birikimine ulaşılamayacağını düşünüp, evrensel bir bilimsel bilginin gelişimi fikrine karşı çıkan post-pozitivistler, Richard Ashley gibi post-modernistlerdir. ${ }^{66}$ Post-modernistler, gerçekçilerden de

57 Robert Keohane 1988'de başkanlığını yaptığı Uluslararası İlişkiler Derneği (International Studies Association, ISA) konferansının açılış konuşmasında yansıtmacı (reflectivist) akımı eleştirmiştir.

58 James Der Derian, “The (S)Pace of International Relations: Simulation, Surveillance, and Speed”, International Studies Quarterly, Cilt 34, No.3, 1990, s.297.

59 Ibid.

60 Pinar Bilgin, “Critical Theory”, Paul Williams (der.), Security Studies: An Introduction, Londra, Routledge, 2008, s. 89-102.

61 Steve Smith, "The United States and the Discipline of International Relations: Hegemonic Country, Hegemonic Discipline”, International Studies Review, Cilt 4, No.2, 2002, s.67-82.

62 Burak Ülman, Evren Balta-Peker ve Muhammed A. Ağcan, “'Uluslararası' Fikri, Epistemolojik Yanılgı ve Eleştirel Gerçekliğin İmkânları”, Uluslararası İlişkiler, Cilt 8, Sayı 30, 2011, s.15-41.

63 Heikki Patomaki ve Colin Wight, "After Postpositivism? The Promises of Critical Realism”, International Studies Quarterly, Cilt 44, No.2, 2000, s.213-237.

64 Robert Cox, "Social Forces, States and World Orders: Beyond International Relations Theory", Millenium Journal of International Studies, Cilt 10, No.2, s.126-157.

65 Ibid.

66 Ashley, Robert K. and R. B. J. Walker (1990). "Introduction: Speaking the Language of Exile: Dissident Thought in International Studies." International Studies Quarterly, Cilt, 34, No.3, s.259-268. 
karamsar bir dünya görüşüne sahiptirler ve sadece bilimsel bilgi ile nesnel gerçekliği reddetmekle kalmaz, gerçekliği de tamamen yadsırlar. Gerçeklik dile, fikirlere ve kültüre göre sürekli değiştiğinden, post-modernistlerin kullanmakta anlaştıkları tek yöntemin dil ve söylem analizi olduğu iddia edilebilir. Bu çerçevede sayısal metotların kullanımına tamamen karşı çıkan post-pozitivist yaklaşım post-modernizmdir. Bu çerçevede, Uluslararası İlişkileri post-pozitivist felsefe ile çalışan çoğu kişi, araştırmanın biri veya bir şey için yapıldığı düşüncesiyle, çareyi pozitivist paradigmanın tamamını reddetmekte bulmuştur. Bu reddediş içinde, pozitivistlerin kullandığı yöntemler de yer almış, dolayısıyla post-pozitivist kuramlara faydası olabilecek içerik analizi gibi metotlar da topyekûn reddedilmiştir. ${ }^{67}$

Daha önce de belirtildiği gibi bu makale, pozitivizm/post-pozitivizm tartışmasında pozitivist metodolojiyi tutucu ve statik bulan, kullandığı metotları reddeden yaklaşımlara karşı orta yolu savunan yaklaşımları ve mantığı tanıtmayı hedeflemektedir. Öyle ki, problem çözücü yaklaşımı olan kuramlar problemleri mevcut sistem içinde çözmeye çalışırlarken, aslında bunu sadece mevcut sistemi korumak için değil, sorunları saptayıp onlara kısa ve uzun vadede çözüm bulma maksadıyla da yapabilmektedirler. Yani bilimsel bilgi olanı ve olmayanı saptarken, olmayanı sağlamak bu saptamanın sonucunda beklenendir. Buna karşılık öncelik sorunu tanımlamaktır; çözüm ancak ondan sonra bulunabilir. En sonda ise statükonun değiştirilip değiştirilemeyeceği kaygısı gelir. Dolayısıyla kullanılan yöntemlerin saptama, ölçme ve genel eğilimleri belirleme hedefi bulunmaktadır. İşte bu sebeple de bu hedefler kullanılan yöntemleri pozitivizme has kılmaz, çünkü yöntem sadece bir araçtır; ne şekilde ve ne amaçla kullanılacağı araştırmacının tasarrufundadır.

Örneğin, bu bağlamda kendini pozitivist olarak tanımlayan ve çalışmalarında formel yöntemleri tercih eden nadir Avrupalı uluslararası ilişkiler uzmanlarından olan Michael Nicholson, postpozitivistlerin sadece kendilerinin özgürleş(tir)me (emancipation) peşinde olduğunu düşünmelerini eleştirmiştir. ${ }^{68}$ Nicholson'a göre, AIDS’in neden ortaya çıktığını anlatmaya çalışmak, onu anlamadığınız ya da varoluşunu onayladığınız anlamına gelmez; sadece bu hastalığın insanları öldürmesini engelleyebilmek için bilimsel kavramlar ve yöntemler (hipotez, değişkenler, ölçüm, deney) kullanmanız gerekmektedir. Dünyada hastalık hep var olacaktır ve tüm hastalıklardan sonsuza dek kurtulabilmek mümkün olmadığından, onları daha iyi anlayıp sebeplerini anlatabilmek gerekmektedir. Diğer bir deyişle Nicholson, pozitivistler tarafından kullanılan bilimsel yöntemlerin neyin değiştirilip neyin değiştirilemeyeceğini bulmak için kullanılması taraftarıdır. Özgürleşme ancak bu tarz bir analizin sonrasında söz konusu olabilir.

Öte yandan, Nicholson’a göre uluslararası ilişkilerde olup bitenleri anlamlandırıp anlatabilmek için olayların akışının belli şartlar altında ne şekilde olmuş olabileceğini kuramlaştırmak gerekir. ${ }^{69} \mathrm{Bu}-$ nun için de yazar, matematiksel ve formel yöntemlerin kuram geliştirmede faydalı olabileceğini savunur. En önemlisi Nicholson, her kuramın matematiksel olarak ortaya konması gerektiğini iddia etmez, fakat bu şekilde ortaya konmuş kuramların mantıksal hata içermeyeceği için daha sağlıklı şekillendirilebileceği kanısındadır. ${ }^{70}$ Nicholson’nn verdiği örnek şudur: Nasıl ki sevgi sözcükleri Fransızca söylendiğinde kulağa daha etkili geliyorsa, metotta da aynı şey geçerlidir; belli konularda bazı kuramlar matematiksel olarak ifade edildiğinde daha etkili ifade edilirler. Sonuçta Fransızca bilmiyoruz diye bu

67 Herrera ve Braumoeller, "Symposium: Discourse and Content Analysis", p.17-18.

68 Michael Nicholson, "What is the Use of International Relations?" Review of International Studies, Cilt 26, No.4, 2000, s.183-198.

69 Michael Nicholson, "Formal Methods in International Relations", Frank Paul Harvey ve Michael Brecher (der.), Evaluating Methodology in International Studies, MI, University of Michigan Press, 2002, s.24.

70 Ibid. 
dilin romantikliğini yadsımayız ama hiç Fransızca bilmiyor ya da öğrenme hevesi duymuyorsak da, aşkımızı ifade etmek için bu dili öğrenmeye çalışmayız. ${ }^{11} \mathrm{Bu}$ daha ılımlı pozitivist bakış açısı makalenin sonraki bölümde tartıştığı analitik uzlaştırmacı Uluslararası İlişkiler yaklaşımının çıkış noktasını anlamak açısından önemlidir.

Bu tarz sorgulamalar pozitivist çalışmalarda son yirmi yılda artmıştır. Örneğin, Zeev Maoz’un bir araya getirdiği pozitivist gelenekten gelen yazarlar, çatışma yönetimi ve çözümlenmesi konularında değişik metotlar kullanmanın varılan cevabı etkileyerek tutarsız sonuçlara gidilmesini sağlayıp sağlamadığını irdelemişlerdir. ${ }^{72}$ Kitapta pozitivist paradigma içinde kullanılan pek çok değişik metodun farklı soruların cevaplanmasında kullanılması gerektiği sonucuna varılmıştır. Bu açıdan oyun kuramı, istatistik, simülasyon, deney, olay çalışmaları kabul gören yöntemlerken; pozitivist bir uzlaştırmacılık çabası olarak bilimsel bilgi arayışı için aynı soruyu farklı şekillerde cevaplama (triangulation) tavsiye edilmektedir. Bu tarz bir bilimsel çalışmanın ve yöntem kullanımının nasıl olması gerektiğine dair örneklerin incelendiği çalışmalar da gitgide artmaktadır. ${ }^{73}$

Öte yandan post-pozitivist felsefe ile sosyal araştırma yapan kuramlar da yöntemle ilgili benzer arayışlara girmeye başlamıştır. Örneğin Brooke Ackerly, Maria Stern ve Jacqui True eleştirel feminist yazında araştırmanın nasıl yapılması gerektiğine dair fazla bir kaynağın bulunmamasının eksiklik olduğunu iddia etmektedirler. ${ }^{74}$ Buna göre, kuramı feminist yapan sorduğu araştırma soruları ve kuramsal paydalarıdır, kullandığı araç ya da yöntemler değil; dolayısıyla feminist kuramda nitel yöntemler kadar nicel yöntemler de kullanabilir. ${ }^{75}$ Bu kanıyı paylaşmayan Tickner ise, eleştirel kuram, postmodernizm, tarihsel sosyoloji gibi yaklaşımları da içine alan post-pozitivist Uluslararası İlişkilerin özellikle ABD'de sosyal bilimler metodolojisinin baskın olduğu 1980'lerde, üçüncü tartışmanın başladığ sıralarda ortaya çıktığına işaret etmiştir. ${ }^{76} \mathrm{O}$ dönemde, Uluslararası İlişkilere kadının gözüyle bakarak sorular sorulmadığından bu konuda pozitivist yöntemler kullanılarak toplanmış veri de bulunmamaktadır. ${ }^{77}$ Yani Tickner'a göre, feminist bakış açısıyla dünya politikası çalışanlar, klasik bilimsel yöntemleri kullanamamışlardır, çünkü sordukları sorular bu yöntemlerle cevaplanamayacak sorulardır. Diğer bir deyişle, yöntem soruya göre belirlenmelidir. Bu yaklaşım da bir sonraki bölümde detaylandırılacak analitik uzlaştırmacı bir Uluslararası İlişkiler metot yaklaşımına uygundur.

Nitekim David Lake farklı epistemolojik, ontolojik ve metodolojik kaygılar ile gerçekleştirilen Uluslararası İlişkiler çalışmalarının birbirlerini dışlamak yerine tamamlamak üzerine yoğunlaşması gerektiğini ileri sürmektedir. ${ }^{78}$ Lake pozitivizm/post-pozitivizm tartışmasındaki tarafları köktendinci grupların anlaşmazlıklarına benzetir; çünkü çeşitli farklılıkların tarafları birbirlerinin kullandığı yöntemleri tamamen reddetmeye götürmesi disipline uzun yıllar zarar vermiştir. Yine de metotla ilgili tartışmaların ortaya çıkması aslında Uluslararası İlişkiler disiplininin bir disiplin haline gelmesinin ge-

71 Ibid.

72 Zeev Maoz, Multiple Paths to Knowledge in International Relations: Methodology in the Study of Conflict Management and Conflict Resolution, Lexington Books, 2004.

73 Sara McLaughlin Mitchell, Paul F. Diehl, ve James D. Morrow (der.), Guide to the Scientific Study of International Processes, West Sussex, Wiley-Blackwell, 2012.

74 Brooke Ackerly, Maria Stern ve Jacqui True (der.), Feminist Methodologies in International Relations, NY, Cambridge University Press, 2006, s.2.

75 Ibid., s.5.

76 Tickner, "Feminism Meets International Relations", s.19.

77 Ibid., s.40-41.

78 David A. Lake, "Why "Isms" Are Evil: Theory, Epistemology, and Academic Sects as Impediments to Understanding and Progress", International Studies Quarterly, Cilt 55, No.2, 2011, s.465-80. 
reğidir. ${ }^{79}$ Başka disiplinlerin yarım asırdır ele aldığı metodoloji konuları Uluslararası İlişkilerde bu tartışma sayesinde incelenmeye başlandığından, söz konusu tartışmanın disipline katkısı yadsınamaz. ${ }^{80}$

Yine de tartışmanın yapıcı bir doğrultuda ilerlemesi pek mümkün olmadığından, yöntem kullanımı açısından ayrılıklar iki tarafı birleştirmekten ziyade kutuplaştırmıştır. Öyle ki, Barry Buzan ve Richard Little akılcılar ve post-modernistlerin uzlaşmaz tavırlarını eleştirerek, inşacıların (constructivist) tarih, metodolojik çoğulculuk ile büyük kuramlara sıcak bakmalarına rağmen epistemolojik, ontolojik ve yöntemsel kavganın hakim olduğu bu ortamda kimseye yaranamadıklarını saptamışlardır. ${ }^{81}$ Buna göre, Uluslararası İlişkilerde inşacılığın öncüsü sayılan Alexander Wendt, disiplinde süregelen metodolojik tartışmaların çoğuna konuya yanlış ikilikler ile bakmanın sebep olduğunu ve bu tartışmalarda orta yolu bulmanın aslında çok da zor olmadığını söylemektedir. ${ }^{82}$ Zaten yöntemsel olarak inşacı yaklaşımın eleştirel ve akılcı kuramların metodoloji anlayışlarına göre nispeten orta yolu izlediği de söylenebilir. ${ }^{83}$ Bu sebeple analitik uzlaştırmacılık gibi pragmatik bir bakış açısının inşacı gelenekten gelen yazarlardan çıkması şaşırtıcı değildir. Bir sonraki bölüm hem bu yaklaşımı kısaca inceleyecek, hem de metoda odaklanmayan bu yaklaşımdan metot konusunda öğrenilebilecekleri kısaca örnekleyecektir.

\section{Analitik Uzlaştırmacılık ve Metot}

Peter Katzenstein, analitik uzlaştırmacılık görüşünün temellerini 1995'te yazdığı artık klasikleşmiş makalesinde atmıştır. ${ }^{84}$ Katzenstein'e göre zaman içerisinde kuram ve yöntem ayrışmaları dünya politikasıyla ilgili önemli ve ilgi çekici sorular sorulmasının önüne geçmiştir. Öyle ki, yukarıda ele alındığı gibi, Katzenstein'ın bu eleştiriyi yapmasının üzerinden geçen yıllarda da pozitivist ve post-pozitivist eğilimli akademisyenler arasında çok şiddetli epistemoloji ve ontoloji tartışmaları yaşanmıştır. Analitik uzlaştırmacılık kavramı pozitivizm/post-pozitivizm tartışmasının kısırlığından sıkılanların etrafında toplandığı tek yaklaşım da değildir. Örneğin eleştirel gerçekçilik olarak adlandırılan bilim felsefesini anlatan Faruk Yalvaç, bu felsefeyi post-pozitivizm sonrası bir alternatif olarak nitelemektedir. ${ }^{85}$ Öte yandan Buzan ve Little da İngiliz Okulu'nun tarih ve Uluslararası İlişkilerin yeniden evlendirilmesi için çaba harcaması gerektiğini söylemiş, on yıllar önce disiplinin yöntem konusunda bilinçsiz olduğunu, artık başkalarının yöntemlerini kullanmak yerine Uluslararası İlişkilerin bilinçli bir yöntem sentezi bulması gerektiğini ifade etmişlerdir. ${ }^{86}$ Yani Katzenstein' ın başlattığı ve daha sonra Rudra Sil ile geliştirdiği yaklaşım, yukarıda örneklendiği üzere hem bazı pozitivist hem de bazı post-pozitivistlerin ihtiyaç hissettiği bir uzlaşma güdüsünün yansımasıdır.

Christian Reus-Smit'in de dediği gibi, Katzenstein'in yaklaşımı aslında meta-teori karşıtıdır, çünkü ontolojik kaygıları bir kenara koyarak ve gerçek dünya sorunlarına eğilerek bilginin her zaman konumlandırılmış iletişim ve araştırma sonucu oluştuğunu, bunun için de pragmatik tavırla daha iyi

79 Jackson ve Sorenson, Introduction to International Relations, s.218.

80 Özlük, "Gelenekselcilik-Davranışsalcılık Tartışmasını Bağlamında Anlamak”, s.202.

81 Buzan ve Little, "Why International Relations Has Failed”, s.32.

82 Buzan ve Little, Wendt'in tartışıldığı bir dergi özel sayısını da salık vermektedirler: "Forum on Alexander Wendt's Social Theory of International Politics," Review of International Studies, Cilt 26, No.1, 2000, s.123-80.

83 Nil Şatana ve Burak Bilgehan Özpek, “ABD ve Türkiye’de Geçmişten Günümüze Güvenlik Çalışmaları”, Ortadoğu Etütleri, Cilt 1, No.2, 2010, s.89.

84 Peter J. Katzenstein et.al., "The Role of Theory in Comparative Politics: A Symposium”, World Politics, Cilt 48, No.1, 1995, s.1-49.

85 Faruk Yalvaç, "Eleștirel Gerçekçilik: Uluslararası Ilişkiler Kuramında Post- Pozitivizm Sonrası Așama”, Uluslararası Ilișkiler, Cilt 6, Sayı 24, 2010, s.3-32.

86 Buzan ve Little, "Why International Relations Has Failed”, s.32. 
araştırma yapmayı sağlayacak metodun kullanılması gerektiğini iddia etmektedir. ${ }^{87} \mathrm{Bu}$ açıdan analitik uzlaştırmacılık, Friedrichs ve Kratochwil'in pragmatik yaklaşımlar için tanımladığı iki ölçüte de uymaktadır: Bilgi üretiminin sosyal ve çözümlemeci olduğunun kabulü ile faydalı ve kullanılabilir bilgi üretimi için araştırma yöntemleri geliştirilmesi. ${ }^{88}$ Nitekim, disiplinleri birbirinden ayıran aslında bilgi üretirken kullandıkları metotların farklılığı değil, neyi bilgi olarak gördükleridir. ${ }^{89} \mathrm{Bu}$ sebeple de, Uluslararası İlişkilerin metotlarını hangi disiplinden ödünç aldığına odaklanmak yerine, bilgi olarak görülen her ne ise ona ulaşmak için yöntem konusunda pragmatik olmakta bir sakınca yoktur.

Sil ve Katzenstein gerçekçilik, inşacılık, liberalizm gibi kuramların yarattıkları paradigmaların güçlü ve zayıf yanlarını anlatmakla kalmamışlar, aynı zamanda bu paradigmaların 1990-2000 yılları arasındaki birçok gelişmeyi anlamlandırabilmek için evrildiklerini de iddia etmişlerdir. ${ }^{90}$ Her ne kadar bu evrilmenin bir sonucu değişik kuramların değişik konuları sorunsallaştırmalarıysa da, epistemolojik ve ontolojik farklılıklara odaklanıldığından Uluslararası İlişkiler disiplini metot konusunda bu paradigmaların birbirlerine ögretecekleri derslerden faydalanamamıştır.

Sil ve Katzenstein, analitik uzlaştırmacılık yaklaşımını daha çok kuramsal açıdan değerlendirmiş, metot konusuna detaylı girmemişlerdir. Fakat, kullandıkları mantığı metot konusuna uygulamamak için bir sebep yoktur. Nasıl ki kuramı dünya politikasında yaşanan farklı sorunları anlamak (ya da açıllamak) için pragmatik bir şekilde kullanmak gerekiyorsa, yöntem de bir alet çantasının içindeki farklı aletlerle eşdeğer görülebilir.

Yöntem seçimi, nasıl araştırma yapılması gerektiğine ve nasıl bir araştırmacı tavrının tercih edildiğine karar vermeyi gerektirir. Uluslararası İlişkiler araştırmacıları farklı amaçlar için farklı araştırma yöntemleri kullanırlar. Araştırmacının ideolojik ya da kuramsal altyapısı ne olursa olsun, "analiz nesnelerimizi nasıl tanımladığımızı, belli bir sorunu çalışmaya karar verme sebebimizi ve bir yaklaşımı ihtiyacımız olan fikir ve verileri toplamak için neden diğerlerinden daha faydalı bulduğumuzu bilinçli bir şekilde değerlendirmek önemlidir" ${ }^{91}$ Örneğin, toplumun belli bir dış politikaya nasıl tepki verdiğini görmek için en uygun yöntem anket yöntemiyken, aynı yöntemi siyasi elitin dış politika eğilimlerini çalışmak için kullanmak verimli bir sonuç vermeyebilir. Onun yerine ayrıntılı elit mülakatı yapmak ya da politika yapıcıların söylemlerini incelemek faydalı olacaktır. Analitik uzlaştırmacı yaklaşım kullanılabilir bilgi üretmek için hangi yöntemin hangi soruları cevaplamak için en faydalı olacağını düşünerek araştırılma yapılmasını önermektedir.

Öte yandan post-pozitivist yaklaşımların incelenmesini elzem bulduğu dil ve söylem analizi gibi metotların gelişmesi de bu tarz uzlaştırmacı bir tavırdan geçebilir. Uzun yıllar boyunca pozitivistler metot kullanımını kendi tekelleri altında görmüş, bu yanlış algılamayı post-pozitivistlerden radikal uçlarda olanlar da kuvvetlendirmişlerdir. Fakat işin doğrusu, yöntem kullanımı pozitivistlerin tekelinde olmadığı gibi, gerektiğinde sorunsallaştırılan konunun anlaşılmasında yardımı olacaksa geniş yelpazede yöntem kullanımı tüm post-pozitivist yaklaşımlar tarafından da reddedilmemektedir. ${ }^{92}$

87 Christian Reus-Smit, "The Contours of Analytical Eclecticism”, http://pacs.einaudi.cornell.edu/system/files/ ReusSmit-PKFest1.pdf (Erişim Tarihi: 10 Mayıs 2013).

88 Friedrichs ve Kratochwil, “On Acting and Knowing”, s.701-731.

89 Erol Kurubaş, “Türkiye Uluslararası İlişkiler Yazınında Tarihsel Olguculuk ile Disiplinlerarasıcılığın Analitik Yaklaşıma Etkisi ve Türkiye Uygulaması”, Uluslararası Ilişkiler, Cilt 5, Sayı 17, 2008, s.129-159.

90 Sil ve Katzenstein, Beyond Paradigms, s.58.

91 Nil Şatana, "Sosyal Araştırma, Yaklaşım ve Beceriler”, TUBA Açık Ders: http://www.acikders.org.tr/course/vıew. php?id=128 (Erişim Tarihi: 25 Mayıs 2013).

92 Mark B. Salter ve Can E. Mutlu, Research Methods in Critical Security Studies: An Introduction, Taylor \& Francis Group, 2012. 
Sil ve Katzenstein’ın kitaplarında geliştirdikleri analitik uzlaştırmacı yaklaşımın metot kullanımı konusunda faydasını örneklemek için kısaca terörizm çalışmalarına bakmak yeterlidir. 11 Eylül 2001 saldırılarına kadar pek de gelişmiş bir alt alan olmayan terörizm çalışmaları, 1990'larda daha çok farklı terör örgütlerinin olay incelemesi yapılarak, özellikle de İslami terörün özel bir olay olduğu savından yola çıkmaktaydı. Konuyu çalışanlar Uluslararası İlişkiler araştırmacılarından ziyade siyaset bilimciler olduğundan realist, liberal ya da eleştirel kuramların kullanılarak çalışıldığı bir literatür henüz gelişmemişti. 11 Eylül sonrasında ise, Maryland Üniversitesi’nde disiplinlerarası bir çabayla Küresel Terörizm Veritabanı (Global Terrorism Database, GTD) gibi veri tabanlarının oluşturulması girişimi ve terör örgütlerinin profillenmesi ile bunların genel eğilimlerinin sayısal yöntemlerle incelenmesi gibi çalışmalar ivme kazanmıştır. Bu çalışmaların ana amacı, devleti devlet-dışı aktörlerin saldırılarından korumak olduğundan ve birey yerine devletin güvenliğine odaklandıklarından, devlet bazlı veri toplanması ve yöntem kullanımı (istatistik, anket vs.) yaygınlaşmıştır. Terörizmi önlemek amacı güdüldüğünden de terörizmin aslında devletler arası savaşlar gibi önlenebilecek ya da bir anda sona erdirilebilecek bir olgu olmadığı, daha ziyade uzun vadede yönetilmesi gereken bir olgu olduğu gözden kaçmıştır. ${ }^{93}$

$\mathrm{Bu}$ eksikliğin farkına varan eleştirel kuram çalışanları, Robert Jackson önderliğinde Aberystwyth'te bir araya gelerek eleştirel terörizm çalışmaları altında post-pozitivist bir yaklaşımla farklı sorular sormuşlar, aradıkları cevaplar için farklı yöntemler kullanmışlardır. ${ }^{94}$ Barry Buzan bir çalışmasında 11 Eylül sonrasında terörizm tanımlamasındaki sorunları ele almış, kavramların çeşitli politik sebeplerle oluşturulmasının aslında 11 Eylül sonrası dünyada nasıl algı değişiklikleri yarattığını göstererek terörizm literatürüne katkıda bulunmuş, bunu da hem söylem hem de olay analizi yaparak başarmıştır. ${ }^{95}$ Aynı süreçte teröriste ve onun güdülerine (örneğin gayrı safi milli hasılanın terörist örgüte katılıma etkisi) odaklanılarak yapılan çalışmalar yerine, teröristin savaştığı tarafin yani devletler ve kişilerin söylemlerinin anlaşılmasının gerekliliği ortaya çıkmış, bunun için de söylem analizi yöntemi kullanılmaya başlanmıştır. ${ }^{96} \mathrm{Bu}$ çerçevede somut yöntemleri olmadığından şikâyet edilen post-pozitivist terörizm çalışmaları için söylem analizi yönteminin geliştirilmesi önemli bir gelişme olmuştur. ${ }^{97}$ Daha önce söylemin önemini anlamaya başlayıp içerik analizi metodunu geliştiren pozitivist yaklaşım için söylem analizi yeteri kadar bilimsel görülmese de, terörizm çalışmalarında bu yaklaşımdan elde edilen anlayış faydalı olmuştur. Son yıllarda bu sebeple terörizm çalışmaları giderek daha disiplinler arası bir nitelik almaya başlamış ve analitik uzlaştırmacı bir tavır giderek bu alt alanı etkilemeye başlamıştır.

Analitik uzlaştırmacı bir yaklaşımı benimseyen Şatana, Inman ve Birnir ise çalışmalarında, GTD veri tabanı kapsamında terörist saldırı olarak tanımlanan şiddet olaylarında dini azınlıkların rolüne bakmakta, dini bir şiddet unsuru olarak gösteren ve radikal İslam’a odaklanan vaka çalışmalarının aslında Müslümanları daha çok yabancılaştırdığı varsayımından yola çıkmaktadırlar. ${ }^{98}$ Aynı

93 Gary LaFree, “Criminology's Third War”, Criminology \& Public Policy, Cilt 8, No.3, 2009, s.431.

94 Robert Jackson, "Constructing Enemies: "Islamic Terrorism” in Political and Academic Discourse”, Government and Opposition, Cilt 42, No.3, 2007, s.394-426; Robert Jackson, "Symposium: Introduction: The Case for Critical Terrorism Studies”, European Political Science, Cilt 6, No.3, 2007, s.225-227.

95 Barry Buzan, “Will the ‘Global War on Terrorism’ Be the New Cold War?”, International Affairs, Cilt 82, No.6, 2006, s.1102.

96 Rainer Hülsse ve Alexander Spencer, “The Metaphor of Terror: Terrorism Studies and the Constructivist Turn”, Security Dialogue, Cilt 39, No.6, 2008, s.571-92.

97 Jacop L. Stump ve Priya Dixit, Critical Terrorism Studies: An Introduction to Research Methods, NY, Routledge, 2013.

98 Nil S. Satana, Molly Inman ve Jóhanna Kristín Birnir, “Religion, Government Coalitions, and Terrorism”, Terrorism and Political Violence, Cilt 25, No.1, 2013, s.29-52. 
yaklaşım eleştirel terörizm çalışmaları tarafindan da paylaşılmaktadır. Bu sebeple Şatana, Inman ve Birnir derinlemesine yapılan terör örgütü çalışmalarının hep İslami örgütlere ve İslamiyetin şiddeti tetiklediği varsayımına odaklanmasını eleştirip, bir dinin terörizme bir diğerinden daha yatkın olup olmadığı sorusunu nicel veri toplayarak incelemiştir. ${ }^{99}$ Yazarlar pozitivist bir paradigmanın varsayımlarıyla çalışmadıkları gibi, yöntemsel bir sınırlamayı da kabul etmediklerinden, sadece sayısal veri toplamamış, terör örgütlerinin söylemlerini de inceleyerek azınlıkların bunlara katılım süreçlerinin seçimlerle ilişkisini irdelemişlerdir. Ayrıca çalışmada olay analizi yapılarak genel bulgulara uymayan ülkelerin çalışılması gerekliliği de önerilmiştir. Burada önemli olan pragmatik bir tavırla sorunsallaştırılan olayın en uygun yöntemlerle derinlemesine incelenmesidir. Kullanılan yöntemlerin her biri sorulan sorunun farklı bir yanını anlamak için önem taşımaktadır. Özellikle de soru, İslam neden ve nasıl terörizme sebep olur yerine, din her ülkede ve grupta şiddete sebep olur mu şeklinde sorulduğunda, nitel yöntemlerle İslamiyet'i terörizme yatkın olmakla itham eden çoğunluğu ABD'de yapılmış ideolojik çalışmaların bulguları, ${ }^{100}$ nicel ve nitel yöntemler bir arada kullanılarak çürütülebilir.

Sonuçta burada bahsi geçen çalışmalar, sorulan sorunun niteliğine göre yöntem seçiminde bulunduklarından, terörizm hakkındaki önyargıların oluşturduğu pek de bilimsel olmayan bir anlayışı değiştirmeye ve geliştirmeye başlamışlardır. Terörizm çalışmaları buna sadece bir örnektir; aynı olgu dış politika çalışmaları ya da nükleer çalışmalarda da gözlemlenebilir. Zira analitik uzlaştırmacı yaklaşım açısından metot, çeşitli kuramsal yaklaşımların kullanımına açıktır ve kullanımları alet çantasındaki çeşitli aletlerden farksızdır. Önemli olan çalışılan alan her ne olursa olsun, Uluslararası İlişkileri anlamlandırma çabasının disiplini kısırlaştıran bir şekilde değil, çoğulcu bir anlayışla ve sorulan sorulara çoklu yöntemler kullanılarak yaklaşılmasının faydasını anlamaktır.

\section{Sonuç}

Birinci Dünya Savaşı sonrası ütopyacı liberaller insanı rasyonel olarak tanımlamış ve insan doğasının doğuştan kötü olmadığını varsayarak, devletlerarası işbirliğinin olası olduğunu iddia etmişlerdi. Nasıl ki bu kuram İkinci Dünya Savaşı'nın çıkması ile geçerliliğini yitirdiyse, Sovyetler Birliği’nin beklenmedik şekilde süper güç olarak ortaya çıkması ile başlayan Soğuk Savaş’ın tarihsel süreci de klasik gerçekçiliğin yerini, uluslararası sistemi öne çıkaran yeni-gerçekçiliğe bırakmasına yol açmıştır. Bu değişimin sebebi aslında dünyadaki değişimler sonucu araştırılması gereken soruların da değişmesiydi. İdeolojinin baskın olduğu bu ortamda Uluslararası İlişkileri disiplin olarak kabul ettirmek, ulaşılan bilginin bilimsel olduğunu göstermekten geçtiğinden önce davranışsalcılık, sonra da pozitivizmin ç1kışı aslında şartların gerektirdiği bir yöntemsel tercih olmuştur.

Aynı şekilde Soğuk Savaş’ın bitişini dönemin baskın kuramı yeni-gerçekçiliğin öngörememesi de, bu kuramın da kendinden öncekiler gibi popülerliğini bir ölçüde yitirmesine yol açmıştır. Ortaya çıkan sivil savaş, başarısız devlet, küresel terörizm, insan hakları, sosyal ve ekonomik eşitsizlik, göç gibi yeni sorunlar yalnızca yeni kuramların gerekliliğine işaret etmemiş, aynı zamanda sorulan yeni sorular yeni metotların bulunması ve uygulanmasını da gerektirmiştir. Eski metotlar ise aynı eski kuramlar gibi varlıklarını sürdürmeye devam etmişlerdir; çünkü her ne kadar yeni sorunlar ortaya çıkmışsa da, eskileri de bireylerin dünya görüşleri kolay kolay değişmediğinden varlıklarını sürdürmeye devam et- 
mişlerdir. Bu sebeple Uluslararası İlişkilerde hiçbir kuram ya da yöntem geçerliliğini tam olarak yitirmemekte; her zaman bir grup taraftar bulmaktadır.

Çoğu zaman epistemolojik ve ontolojik görüş farklılığı yaşayan yaklaşımlar metot konusunda da birbirlerini dışladıklarından, büyük metodoloji tartışmalarının kutuplaştırdığı disiplinde kullanılan araştırma yöntemleri sorulan soruya göre değil, kişinin tarafına göre belirlenir olmuştur. Halbuki bir olgunun anlaşılmasında ya da açıklanmasında pragmatik bir yaklaşıma gidilmesi disiplin için son derece gerekli bir yaklaşımdır. Önce davranışsalcı/gelenekselci, sonra da positivist/ post-pozitivist tartışmaları akademisyenleri taraflara ayırdıkça yöntem kullanımı da ideolojikleşmiş, pragmatik yaklaşımlar azalmıştır. Bu makale, Türkiye'de akademik ortamda fazla tartışılmayan Rudra Sil ve Peter Katzenstein'ın kuram ve araştırma programlarının birbirini tamamlayıcılığına dair geliştirdikleri "analitik uzlaştırmacı" yaklaşımının yöntem konusunda da kullanılabileceğini anlatmıştır. Yaklaşımın tanıtımını takiben kısaca terörizm literatüründe böyle bir yaklaşımın kullanılıyor olmasının, nitel ve nicel yöntemleri beraber kullanarak sorulan soruların daha etkili cevaplanmasını sağladığını ve terörizm çalışmaları alanında 1990'lardan itibaren yaratılan önyargıları gidermeye başladığını göstermeye çalışmıştır. Bundan sonraki çalışmalar, bu makaleyi bir ön çalışma olarak düşünerek, terörizm çalışmalarının ya da başka alt alanların pragmatik yaklaşımlardan ve çoklu yöntem kullanımından nasıl yararlandıklarını ve yararlanabileceklerini daha geniş bir şekilde ele almalıdırlar. Burada önemli olan herhangi bir yöntemi sadece epistemolojik ve ontolojik yaklaşıma dayanarak, faydalı olup olmadığını düşünmeden reddetmemek, sorulan soruyu en iyi şekilde cevaplayabilmek için eldeki her imkânı kullanmayı hedeflemektir. Bu anlayış ile Uluslararası İlişkiler disiplini hem kuramsal olarak zenginleşecek, hem de dünya siyasetinde gelişen olguları daha iyi anlamak, açılamak ve yorumlamak mümkün olacaktır. 


\section{Kaynakça}

Ackerly, Brooke, Maria Stern ve Jacqui True (der.), Feminist Methodologies in International Relations, New York, Cambridge University Press, 2006.

Ashley, Richard K. and R. B. J. Walker, "Introduction: Speaking the Language of Exile: Dissident Thought in International Studies”, International Studies Quarterly, Cilt 34, No 3, 1990, s. 259-268.

Aydın, Mustafa, “Uluslararası İlişkilerin “Gerçekçi” Teorisi: Kökeni, Kapsamı, Kritiği”, Uluslararası İlişkiler, Cilt 1, No 1, 2004, s. 33-60.

Aydın, Mustafa, "Uluslararası İlişkilerde Yaklaşım, Teori ve Analiz”, Ankara Üniversitesi Siyasal Bilgiler Fakültesi Dergisi, Cilt 51, No 1, 1996, s. 71-114.

Bilgin, Pınar, “Critical Theory”, Paul Williams (der.), Security Studies: An Introduction, Londra, Routledge, 2008, s. 89-102.

Bull, Hedley, Strategic Studies and Its Critics, Australian National University, 1967.

Bull, Hedley, "International Theory: The Case for a Classical Approach", World Politics, Cilt 18, No 3, 1966, s. 361-377.

Buzan, Barry, “Will the 'Global War on Terrorism' Be the New Cold War?”, International Affairs, Cilt 82, No 6, 2006, s. 1101-1118.

Buzan, Barry ve Richard Little, "Why International Relations Has Failed As An Academic Project And What to Do About It", Millennium: Journal of International Studies, Cilt 30, No 1, 2001, s. 19-39.

Checkel, Jeffrey, "Social Constructivisms in Global and European Politics: A Review Essay", Review of International Studies, Cilt 30, No 2, 2004, s. 229-44.

Checkel, Jeffrey, “The Constructive Turn in International Relations Theory”, World Politics, Cilt 50, No 1, 1998, s. 324-348.

Cox, Robert, "Social Forces, States and World Orders: Beyond International Relations Theory”, Millenium Journal of International Studies, Cilt 10, No 2, s. 126-157.

Der Derian, James, “The (S)Pace of International Relations: Simulation, Surveillance, and Speed”, International Studies Quarterly, Cilt 34, No 3, 1990, s. 295-310.

Deutsch, Karl, “The Place of Behavioral Sciences in Graduate Training in International Relations”, Behavioral Science, Cilt 3, No 1, 1958, s. 278-284.

Devlen, Balkan, Patrick James, and Özgür Özdamar, "The English School, International Relations, and Progress", International Studies Review, Cilt 7, No 2, 2005, s. 171-97.

Doyle, Michael W., Liberal Peace: Selected Essays, New York, Routledge, 2011.

Dunne, Timothy, Inventing International Society: A History of the English School, New York, St. Martin, 1998.

Dunne, Timothy, "Mythology or Methodology? Traditions in International Theory”, Review of International Studies, Cilt 19, No 3, 1993, s. 305-318.

Elman, Colin ve Miriam Fendius Elman (der.), "Lessons from Lakatos", Progress in International Relations Theory, Cambridge, Harvard University Press, 2003, s. 21-68.

Emeklier, Bilgehan, "Uluslararası İlişkiler Disiplininde Epistemolojik Paradigma Tartı̧̧maları: Postpozitivist Kuramlar”, Bilge Strateji, Cilt 3, No 4, 2011, s. 139-184.

"Forum on Alexander Wendt's Social Theory of International Politics", Review of International Studies, Cilt 26, No 1, 2000, s. 123-180.

Feuer, Lewis S., "A Neo-Marxist Conception of Social Science”, Ethics, Cilt 70, No 3, 1960, s. 237-240.

Friedrichs, Jörg ve Friedrich Kratochwil, "On Acting and Knowing: How Pragmatism Can Advance International Relations Research and Methodology”, International Organization, Cilt 63, No 4, 2009, s. 701-731.

Grieco, Joseph M., "Anarchy and the Limits of Cooperation: A Realist Critique of the Newest Liberal Institutionalism”, International Organization, Cilt 42, No 3, Yaz 1988, s. 485-507. 
Griffiths, Martin, Realism, Idealism and International Politics: A Reinterpretation, London, Routledge, 1992.

Herrera, Yoshiko M. ve Bear F. Braumoeller, "Symposium: Discourse and Content Analysis", Qualitative Methods: Newsletter of the American Political Science Association Organized Section on Qualitative Methods, 2004, s. 17.

Hoffman, Bruce, Inside Terrorism, London, Victor Gollancz, 1998.

Holsti, Karl J., The Dividing Discipline: Hegemony and Diversity in International Theory. Boston, Allen \& Unwin, 1985.

Hopf, Ted, "The Promise of Constructivism in International Relations Theory”, International Security, Cilt 23, No 1, 1998, s. 171-200.

Hülsse, Rainer ve Alexander Spencer, "The Metaphor of Terror: Terrorism Studies and the Constructivist Turn”, Security Dialogue, Cilt 39, No 6, 2008, s. 571-592.

Jackson, Patrick Thaddeus, The Conduct of Inquiry in International Relations: Philosophy of Science and Its Implications for the Study of World Politics, Oxon, Routledge, 2011.

Jackson, Robert, “Constructing Enemies: "Islamic Terrorism” in Political and Academic Discourse", Government and Opposition, Cilt 42, No 3, 2007, s. 394-426.

Jackson, Robert, “Symposium: Introduction: The Case for Critical Terrorism Studies”, European Political Science, Cilt 6, No 3, 2007, s. 225-227.

Jackson, Robert ve Georg Sorenson, Introduction to International Relations, New York, Oxford University Press, 1999.

Kaplan, Morton A., “The New Great Debate: Traditionalism vs. Science in International Relations”, World Politics, Cilt 19, No 1, 1966, s. 1-20.

Katzenstein, Peter J.vd., “The Role of Theory in Comparative Politics: A Symposium”, World Politics, Cilt 48, No 1, 1995, s. 1-49.

Keohane, Robert O., After Hegemony: Cooperation and Discord in the World Political Economy, Princeton, Princeton University Press, 1984.

King, Gary, Robert O. Keohane ve Sidney Verba, Designing Social Inquiry. Scientific Inference in Qualitative Research, Princeton, Princeton University Press, 1994.

Knorr, Klaus, ve James N. Rosenau, Contending Approaches to International Politics, Princeton, Princeton University Press, 1969.

Kurubaş, Erol, “Türkiye Uluslararası İlişkiler Yazınında Tarihsel Olguculuk ile Disiplinlerarasıcılığın Analitik Yaklaşıma Etkisi ve Türkiye Uygulaması”, Uluslararası İlişkiler, Cilt 5, No 17, 2008, s. 129-159.

LaFree, Gary, “Criminology’s Third War”, Criminology \& Public Policy, Cilt 8, No 3, 2009, s. 431-444.

Lake, David A. "Why "Isms" Are Evil: Theory, Epistemology, and Academic Sects as Impediments to Understanding and Progress." International Studies Quarterly, Cilt 55, No 2, 2011, s. 465-480.

Lapid, Y., "The Third Debate: On the Prospects of International Theory in a Post-Positivist Era”, International Studies Quarterly, Cilt 33, No 3, 1989, s. 235-254.

Ray, James Lee, Democracy and International Conflict: An Evaluation of the Democratic Peace Proposition, Columbia: University of South Carolina Press, 1995.

Lijphart, Arend, "Comparative Politics and the Comparative Method", The American Political Science Review, Cilt 65, No 3, 1971, s. 682-693.

Maoz, Zeev, Multiple Paths to Knowledge in International Relations: Methodology in the Study of Conflict Management and Conflict Resolution, Lexington Books, 2004.

McLaughlin Mitchell, Sara, Paul F. Diehl, ve James D. Morrow (der.), Guide to the Scientific Study of International Processes, West Sussex, Wiley-Blackwell, 2012.

Mills, C. Wright, The Sociological Imagination, New York, Oxford University Press, 1959. 
Morgenthau, Hans J., "Common Sense and Theories”, H.J. Morgenthau (der), Truth and Power: Essays of a Decade 1960-1970, New York, Praeger, 1970, s. 241-248.

Nicholson, Michael, "What is the Use of International Relations?" Review of International Studies, Cilt 26, No 4, 2000, s. 183-198.

Nicholson, Michael, “Formal Methods in International Relations”, Frank Paul Harvey ve Michael Brecher (der.) Evaluating Methodology in International Studies, Ann Arbor, University of Michigan Press, 2002, s. 23-43.

Özlük, Erdem, "Gelenekselcilik-Davranışsalcılık Tartışmasını Bağlamında Anlamak”, Ankara Üniversitesi SBF Dergisi, Cilt 64, No 3, 2009, s. 197-220.

Patomaki, Heikki and Colin Wight, "After Postpositivism? The Promises of Critical Realism”, International Studies Quarterly, Cilt 44, No 2, 2000, s. 213-237.

Rapaport, A., Fights, Games, and Debates, Ann Arbor, University of Michigan Press, 1960.

Ray, James Lee, Democracy and International Conflict: An Evaluation of the Democratic Peace Proposition, Columbia, University of South Carolina Press, 1995.

Reus-Smit, Christian, “The Contours of Analytical Eclecticism”, http://pacs.einaudi.cornell.edu/system/files/ ReusSmit-PKFest1.pdf. Erişim tarihi: 10 Mayıs 2013.

Rousseau, David L. vd., "Assessing the Dyadic Nature of the Democratic Peace, 1918-1988", American Political Science Review Cilt 90, No 3, 1996, s. 512-533.

Salter, Mark B. ve Can E. Mutlu. Research Methods in Critical Security Studies: An Introduction, Taylor \& Francis Group, 2012.

Satana, Nil S., Molly Inman, ve Johanna K. Birnir, "Religion, Government Coalitions, and Terrorism”, Terrorism and Political Violence, Cilt 25, No 1, 2013, s. 29-52.

Schelling, Thomas C., The Strategy of Conflict, Harvard University Press, 1960.

Sil, Rudra ve Peter J. Katzenstein, Beyond Paradigms. Analytic Eclecticism in the Study of World Politics, New York, Palgrave Macmillan, 2010.

Singer, J. David, “Uluslararası İlişkilerde Analiz Düzeyi Meselesi”, Uluslararası İlişkiler, Cilt 3, No 11, 2006, s. 3-24.

Small, Melvin and J. David Singer, Resort to Arms: International and Civil War,1816-1980, Beverly Hills, CA, Sage, 1982.

Smith, Steve, "The United States and the Discipline of International Relations: Hegemonic Country, Hegemonic Discipline”, International Studies Review, Cilt 4, No 2, 2002, s. 67-82.

Smith, Steve, "New Approaches to International Theory", John Baylis ve Steve Smith (der), The Globalization of World Politics, Oxford, Oxford University Press, 1997, s. 165-190.

Smith, Steve, Ken Booth ve Marysia Zalewski, International Theory: Positivism and Beyond, UK: Cambridge University Press, 1996.

Stump, Jacop L. ve Priya Dixit, Critical Terrorism Studies: An Introduction to Research Methods, New York, Routledge, 2013.

Şatana, Nil, “Sosyal Araştırma, Yaklaşım ve Beceriler”, TUBA Açık Ders: http://www.acikders.org.tr/course/ view.php?id=128. Erişim tarihi: 25 Mayıs 2013.

Şatana, Nil ve Burak Bilgehan Özpek, “ABD ve Türkiye’de Geçmişten Günümüze Güvenlik Çalışmaları,” Ortadoğu Etütleri, Cilt 1, No 2, 2010, s. 75-114.

Tanrısever, Oktay, "Yöntem Sorunu: Gelenekselcilik-Davranışsalcılık Tartışması", Atila Eralp (der.), Devlet, Sistem ve Kimlik. Uluslararası İlişkilerde Temel Yaklaşımlar, İstanbul, İletişim Yayınları, 2009.

“The Qualitative-Quantitative Disputation”, American Political Science Review, Cilt 89, No 2, Haziran 1995.

Tickner, J. Ann, “Feminism Meets International Relations: Some Methodological Issues”, Brooke Ackerly, Maria Stern ve Jacqui True (der.), Feminist Methodologies in International Relations. Cambridge University Press, 2006. 
Thompson, K. W., “The Study of International Politics: A Survey of Trends and Developments”, Review of Politics, Cilt 14, No 4, 1952, s. 433-443.

Ülman, Burak, Balta-Peker, Evren ve Ağcan, Muhammed A., ““Uluslararası” Fikri, Epistemolojik Yanılgı ve Eleştirel Gerçekliğin İmkânları”, Uluslararası İlişkiler, Cilt 8, No 30, Yaz 2011, s. 15-41.

Waever, Ole, “Four Meanings of International Society: A Transatlantic Dialogue”, B.A. Roberson (der.), International Society and the Development of International Relations Theory, Londra, Pinter, 1998.

Waltz, Kenneth N., The Theory of International Politics, Massachusetts, Addison-Wesley, 1979.

Wendt, Alexander E., “The Agent-Structure Problem in International Relations Theory”, International Organization, Cilt 41, No 3, 1987, s. 335-70.

Yalvaç, Faruk, “Eleştirel Gerçekçilik: Uluslararası İlişkiler Kuramında Post- Pozitivizm Sonrası Aşama”, Uluslararası İlişkiler, Cilt 6, No 24, Kış 2010, s. 3-32.

Yurdusev, Nuri, “Analiz Seviyesi ve “Analiz Birimi: Bir Ayrım Argümanı”, Uluslararası İlişkiler, Cilt 4, No 16, Kış 2007-2008, s. 3- 19. 